\title{
Promoção da leitura na escola portuguesa: metodologias e crenças dos professores do Ensino Básico
}

Número 4.

Julio de 2015

Pág. 25 a la 50

\section{Keywords:}

Reading, Reading promotion, methodology, training readers

\author{
Maria da Graça Sardinha \\ Universidade da Beira Interior \\ Fernando José Azevedo \\ Centro de Investigação em Estudos da Criança, Instituto de Educação, Universidade do Minho

\section{Rosa Rato} \\ Centro de Investigação em Estudos da Criança
}

\begin{abstract}
:
This paper presents the results of a research study that was done in the Portuguese district of Castelo Branco in the interior of Portugal. The research study aimed at knowing the methodologies and beliefs of teachers from Basic Education about reading promotion. The sample consists of 134 teachers who underwent an inquiry in four areas. In the first area there is an identification of the subject of the survey, in the second we will know the reading habits of the subjects of the survey, in the third we will know the resources that these subjects use in their practices, and in the last area we will known the methods the subjects used in the classrooms.
\end{abstract}




\section{Introdução}

O professor que a escola do séc. XXI exige é aquele que vê na leitura um processo holístico, sendo que para a sua concretização deve incrementar atividades que estimulem o exercício de atividades metacognitivas (Kelley \& Clausen-Grace, 2013), ensinando o aluno a pensar, a refletir e a ser capaz de ler o mundo de modo crítico (Dewitz, Leahy, Jones \& Sullivan, 2010).

Este estudo apresenta os seguintes objetivos:

1. Caracterizar a amostra a nível do género, grupo etário e formação;

2. Aferir os hábitos de leitura dos professores;

3. Aferir se os recursos usados pelos professores para a promoção de hábitos de leitura nos alunos os ajudam na compreensão do texto e melhoram o respetivo desempenho linguístico;

4. Aferir se os métodos aplicados ajudam a desenvolver a expressão escrita nos alunos.

O ponto de partida para a análise passa pelo perspetivar, a partir do docente, do nível de literacia dos seus respetivos discentes. Uma característica transversal aos quatro objetivos enumerados assenta essencialmente no seu carácter quantitativo, pelo que o recurso a um leque diversificado de medidas estatísticas tornou-se um imperativo, enquanto selo de objetividade e de garantia de cumprimento. Por outras palavras, a presente análise percorre os quatro objetivos e procura que, a partir deles, se possam extrair evidências empíricas, enquadráveis teoricamente.

Globalmente, o estudo procura responder às seguintes questões:

1. Existem diferenças significativas no que concerne às habilitações e às questões do género dos docentes quando desenvolvem a motivação para a leitura dos alunos do $1^{\circ}$ Ciclo do Ensino Básico?

2. Existem diferenças significativas no que concerne aos hábitos de leitura dos professores e consequente motivação dos alunos $1^{\circ}$ Ciclo do Ensino Básico para a leitura?

3. Existem diferenças significativas na formação de leitores no que concerne aos recursos utilizados em sala de aula pelos professores?

4. Existem diferenças significativas, resultantes das metodologias que sustentam as práticas pedagógicas dos professores do $1^{\circ}$ Ciclo do Ensino Básico, no que concerne à promoção da leitura dos seus alunos?

Definimos como população alvo, do nosso inquérito por questionário, os atores, que desenvolvem a sua atividade profissional na área da docência no $1^{\circ}$ Ciclo do Ensino Básico. No cômputo geral, foram objeto de inquirição 134 docentes, dando origem a outros tantos inquéritos por questionário. Estes 134 inquiridos distribuem-se

ISL, vol. 4, 2015, págs. $25-50$ ISNN: $2340-8685$
Sardinha, M. G., Azevedo, F. J. y Rato, R (2015): Promoção da leitura na escola portuguesa: metodologias e crenças dos professores do Ensino Básico, Investigaciones Sobre Lectura, 4, 25-50. 
assimetricamente entre os vários agrupamentos escolares, bem como relativamente à categoria de pertença por género.

O inquérito por questionário é composto por quatro grandes grupos de questões. Em termos genéricos, o guião de inquérito apresenta uma orgânica, que classificaríamos como simples, sobretudo em face do uso, quase em exclusivo de questões fechadas.

\section{Matriz de objetivos do questionário}

Enquadramento do questionário quanto ao projeto aplicado:

Questão da investigação: Os hábitos de leitura, os recursos usados para a promoção da leitura e métodos de ensino dos docentes são os mais eficazes para aumentar os níveis de literacia dos alunos no $1^{\circ}$ ciclo do ensino básico?

\section{Objetivos Gerais:}

1. Caraterizar a amostra a nível do género, grupo etário e formação;

2. Aferir os hábitos de leitura dos professores;

3. Aferir se os recursos usados pelos professores para a promoção de hábitos de leitura nos alunos, ajudam na compreensão do texto e melhoram o desempenho linguístico;

4. Aferir se os métodos aplicados ajudam a desenvolver a expressão escrita nos alunos.

\begin{tabular}{|c|c|}
\hline Objetivos específicos & Itens \\
\hline Caraterizar a amostra & I \\
\hline Verificar se a população inquirida é maioritariamente masculina ou feminina; & 1 \\
\hline Saber que faixa etária predomina na população auscultada; & 2 \\
\hline Saber o tempo de serviço dos docentes; & 3 \\
\hline Saber que habilitações académicas detêm os professores do $1^{\circ}$ ciclo do ensino básico; & 4 \\
\hline Aferir hábitos de leitura & II \\
\hline Verificar com que frequência os professores do $1^{\circ}$ ciclo do ensino básico leem; & 1. \\
\hline $\begin{array}{l}\text { Saber a quantidade de vezes que os docentes levaram os alunos à BE/CRE, no último } \\
\text { mês; }\end{array}$ & 2. \\
\hline Aferir recursos usados na promoção da leitura & III \\
\hline $\begin{array}{l}\text { Apurar a percentagem de docentes que estabelecem parcerias que ajudem a melhorar o } \\
\text { domínio da escrita; }\end{array}$ & 1.1. \\
\hline $\begin{array}{l}\text { Saber que parcerias estabelece o professor para desenvolver competências no domínio } \\
\text { da escrita; }\end{array}$ & 1.2 \\
\hline Saber as atividades que os alunos desenvolvem nas várias parcerias; & 2. \\
\hline Apurar a percentagem de alunos que faz requisição domiciliária de livros na BE/CRE; & 3.1 \\
\hline Verificar com que frequência os alunos requisitam livros; & 3.2 \\
\hline $\begin{array}{l}\text { Apurar a percentagem de docentes que levam livros para trabalhar conteúdos, na sala de } \\
\text { aula; }\end{array}$ & 4.1 \\
\hline Saber as razões que levam os professores a escolher determinado livro; & 4.2 \\
\hline Aferir métodos de ensino no âmbito da leitura & IV \\
\hline Verificar com que frequência os professores apresentam livros infantis aos alunos; & 1.1 \\
\hline $\begin{array}{l}\text { Apurar a percentagem de docentes que desenvolvem atividades no âmbito da Pré- } \\
\text { Leitura; }\end{array}$ & 1.2 \\
\hline Saber a opinião dos professores sobre a fase da Pré-Leitura; & 2. \\
\hline Indagar que atividades os docentes promovem durante a fase da Leitura; & 3. \\
\hline Verificar com que frequência os professores incrementam atividades de Pós-Leitura; & 4.1 \\
\hline Saber que tipos de exercícios de Pós-Leitura o professor propõe aos alunos. & 4.2 \\
\hline
\end{tabular}




\section{Procedimentos}

A aplicação do inquérito aos professores aconteceu durante a segunda quinzena de Junho e a primeira de Julho de 2011, período em que os professores se disponibilizaram para responder ao inquérito distribuído. No distrito de Castelo Branco existem vinte e dois agrupamentos, sendo que a nossa opção caiu em onze agrupamentos: Agrupamento de Escolas Afonso de Paiva; Agrupamento de Escolas Cidade Castelo Branco; Agrupamento de Escolas João Roiz; Agrupamento de Escolas Faria de Vasconcelos; Agrupamento de Escolas José Sanches de Alcains; Agrupamento de Escolas de S. Vicente da Beira (localização no concelho de Castelo Branco); Agrupamento de Escolas João Franco; Agrupamento de Escolas Serra da Gardunha; Agrupamento de Escolas Terras do Xisto (localização no concelho do Fundão); Agrupamento de Escolas A Lã e a Neve; Agrupamento de Escolas do Teixoso (localização no concelho da Covilhã); Agrupamento de Escolas de Proença-a-Nova (localização no concelho de Proença-a-Nova).

Seguindo os trâmites legais, procedemos às diligências imprescindíveis para obtenção da monitorização do inquérito em meio escolar e, para isso, fizemos o pedido de autorização ao Ministério da Educação, onde adquirimos o número de registo em 10 de Maio de 2011, cedido a 9 de Junho de 2011.

\section{Resultados: interpretação}

Da análise dos dados (gráfico 1), podemos observar uma marcada presença do grupo feminino dos inquiridos, tal como seria já expectável, dado estarmos a tratar de uma profissão de professores do $1^{\circ}$ Ciclo do Ensino Básico, que, em termos históricos, tem sido pautada por uma forte presença feminina. Sem querermos entrar nesta questão, em particular, poder-se-á adiantar uma tentativa de explicação para este fato estatisticamente tão vincado. Com efeito, há que ter presente a cultura dominante e as representações sociais (estereótipos) a ela inerentes, onde, ao longo do tempo, tem cabido à mulher o papel expressivo, isto é, o de socializar as crianças, em grande parte em virtude de lhe serem atribuídas características de cariz afetivo e emocional. Para tanto, basta pensarmos na Cartilha Maternal de João de Deus, que tem com ela o próprio nome, ou seja para a mãe e não para o pai.

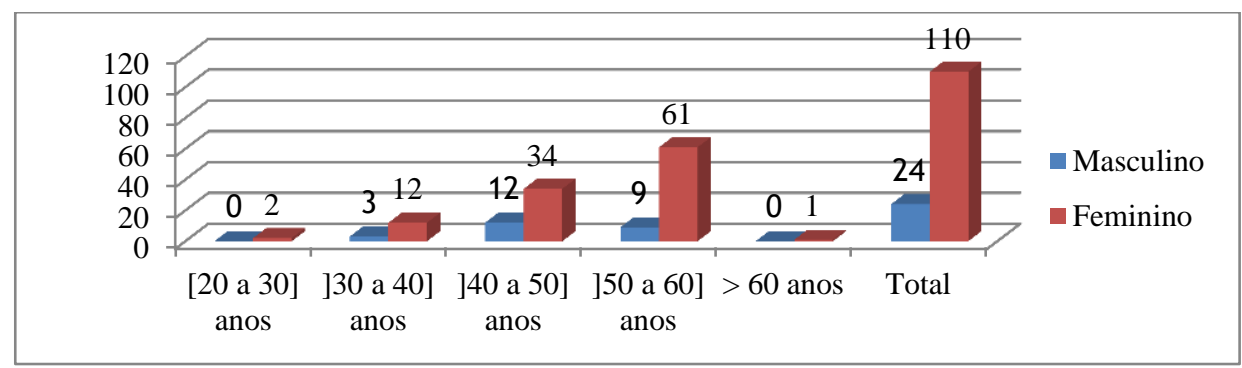

Gráfico 1: Género e Idade dos Inquiridos

ISL, vol. 4, 2015, págs. 25-50 ISNN: $2340-8685$
Sardinha, M. G., Azevedo, F. J. y Rato, R (2015): Promoção da leitura na escola portuguesa: metodologias e crenças dos professores do Ensino Básico, Investigaciones Sobre Lectura, 4, 25-50. 
Neste sentido, podemos observar que $82.1 \%$ dos inquiridos pertence ao género feminino e os restantes $17.9 \%$ ao género masculino. Uma outra vincada ilação que se pode reter da leitura interpretativa do presente gráfico remete para o forte envelhecimento verificado entre os professores do $1^{\circ}$ Ciclo do Ensino Básico. Concretizando, podemos constatar que nas duas categorias etárias mais novas, isto é, aquelas que compreendem [20-30] anos e [30-40] anos apresentam respetivamente 2 casos $(1.5 \%)$ e 15 casos (11.2\%), o que fica no cômputo de ambas, não indo além de uns meros $12.7 \%$, muito aquém das duas categorias seguintes, que apresentam valores bem superiores.

Neste sentido, é expectável que encontremos, entre os inquiridos, a proeminência de longas carreiras. É exatamente este fato que podemos observar no gráfico 2 (Anos de Serviço).

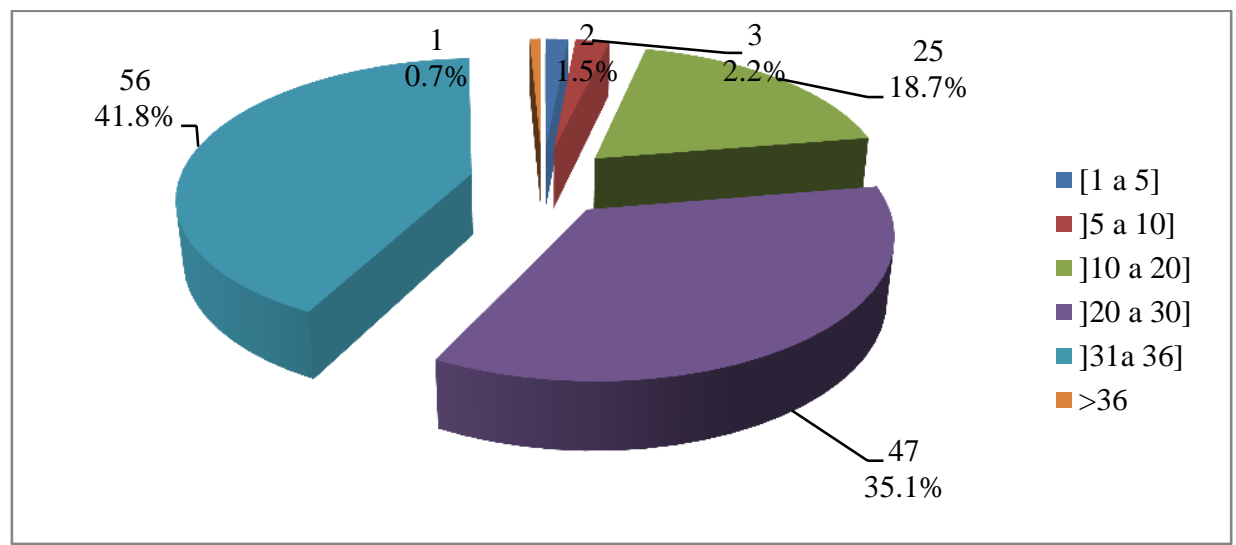

Gráfico 2: Anos de Serviço

Se considerarmos o cômputo das classes que medeiam entre os 20 e 36 anos de carreira, podemos concluir que $76.9 \%$ dos inquiridos tem pelo menos 21 anos de carreira. Por outro lado, nos antípodas desta situação encontram-se as duas categorias, que agregam os docentes inquiridos, com menores percursos profissionais. Concretizando, dir-se-ia que apenas $3.7 \%$ dos inquiridos tem no máximo 10 anos de carreira. Uma última nota para enfatizar o valor residual que a categoria, que congrega os docentes com mais de 36 anos de serviço, obtém com apenas 1 caso $(0.7 \%)$.

Nestes termos, não será de todo surpreendente aferir de que existe uma clara relação entre o número de anos de carreira e a idade, tal como é constatável na Tabela 1 , que resulta do cruzamento da Idade e dos Anos de Serviço, ou seja docentes com idade mais avançada têm mais anos de serviço. 


\begin{tabular}{|c|c|c|c|c|c|c|c|}
\hline & \multicolumn{5}{|c|}{ Idade } & \multirow[b]{2}{*}{ Tota } \\
\hline & & $\begin{array}{c}{[20 \text { a 30] }} \\
\text { anos } \\
\end{array}$ & $\begin{array}{c}{[30 \text { a } 40]} \\
\text { anos }\end{array}$ & $\begin{array}{c}{[40 \text { a } 50]} \\
\text { anos }\end{array}$ & $\begin{array}{c}{[50 \text { a } 60]} \\
\text { anos }\end{array}$ & $\begin{array}{l}>60 \\
\text { anos }\end{array}$ & \\
\hline \multirow{6}{*}{ 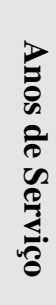 } & [1-5] & 1 & 1 & 0 & 0 & 0 & 2 \\
\hline & {$[5-10]$} & 1 & 2 & 0 & 0 & 0 & 3 \\
\hline & {$[10-20]$} & 0 & 12 & 13 & 0 & 0 & 25 \\
\hline & {$[20-30]$} & 0 & 0 & 33 & 14 & 0 & 47 \\
\hline & [31-36] & 0 & 0 & 0 & 55 & 1 & 56 \\
\hline & $>36$ & 0 & 0 & 0 & 1 & 0 & 1 \\
\hline \multicolumn{2}{|c|}{ Total } & 2 & 15 & 46 & 70 & 1 & 134 \\
\hline
\end{tabular}

Tabela 1: Distribuição dos inquiridos quanto à Idade e Anos de Serviço

Deste modo, os dados até ao momento coligidos adquirem coerência interna, permitindo-nos sublinhar que o perfil do docente inquirido é sobretudo feminino, de idade igual ou superior a 41 anos e que tem já uma longa carreira profissional, ascendendo aos 21 anos. Com efeito, para rematar a caracterização sociográfica da amostra, que dá guarida ao presente estudo, teremos de fazer menção ainda ao grau académico de que estes são portadores. É precisamente nessa linha de raciocínio que apresentamos o gráfico 3 - Habilitações Académicas.

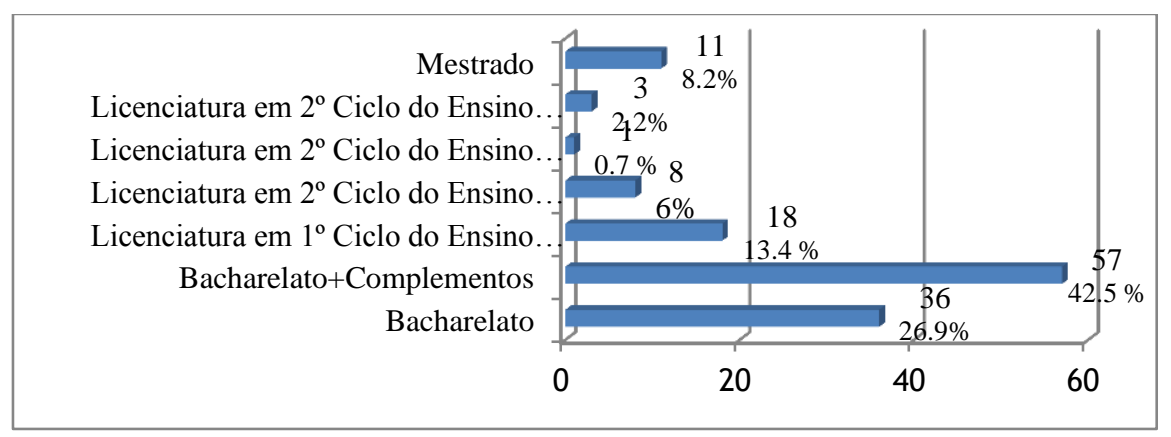

Gráfico 3: Habilitações Académicas

Uma primeira e genérica leitura interpretativa do gráfico 3 leva-nos, de imediato, a reter a ideia de que os que declaram ser detentores de Bacharelato e Bacharelato + Complementos constituem-se como a larga maioria dos inquiridos, somando 69.4\%, sendo que a classe modal é a segunda, alcançando a marca dos $42.5 \%$. Mais, considerando o conjunto das categorias dos que declaram deter Licenciatura, observamos que estes são apenas $8.9 \%$ dos inquiridos. Os detentores de mestrado quantificam, $8.2 \%$. Verifica-se, com efeito, que a grande maioria dos portadores de Bacharelato mas com complementos se concentra nas categorias com mais anos de serviço.

Em antevisão, poder-se-á levantar a possibilidade de, num futuro próximo, por intermédio da substituição das gerações, por via da reforma dos docentes com maior

ISL, vol. 4, 2015, págs. 25-50 ISNN: $2340-8685$
Sardinha, M. G., Azevedo, F. J. y Rato, R (2015): Promoção da leitura na escola portuguesa: metodologias e crenças dos professores do Ensino Básico, Investigaciones Sobre Lectura, 4, 25-50. 
idade, as habilitações tenderem para uma uniformização, apresentando-se todos os professores como detentores do grau de licenciado ou de mestre.

Passando à análise de uma dimensão mais prática do quotidiano da docência no $1^{\circ}$ Ciclo do Ensino Básico, questionou-se a amostra acerca da realização de exercícios em que a leitura é o centro das preocupações. Para tal, constituiu-se uma bateria de perguntas onde se questionava a frequência, com que se lê livros, jornais, para além de revistas e enciclopédias (Gráfico 4).

Ora, podemos, desde logo, verificar, que existe uma tendência de antagonismo, onde num polo se encontra a frequência com que se lê livros e jornais, por um lado, e por outro, enciclopédias, sendo que a leitura de revistas se encontra numa condição intermédia.

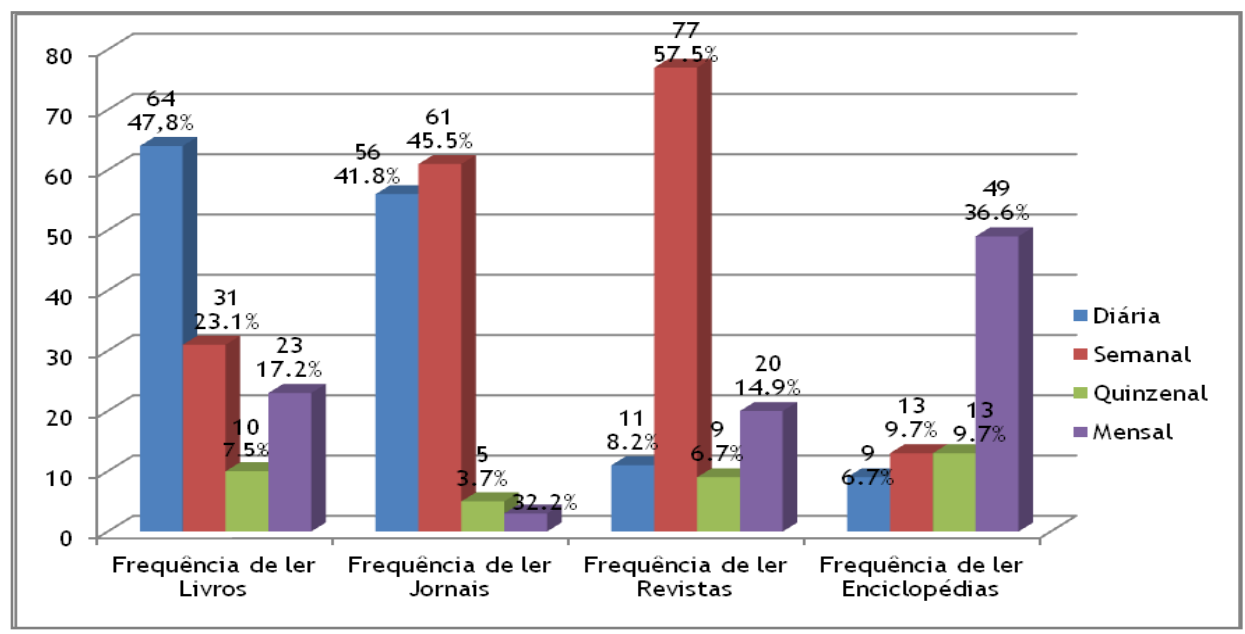

Gráfico 4: Frequência de Leitura

Desta forma, e somando as parcelas de frequência de leitura diária e semanal, podemos constatar um valor de $70.9 \%$ para os livros e um valor de $87.3 \%$ para a leitura de jornais. Nos antípodas deste panorama, encontra-se a leitura de enciclopédias que não vai além dos $16.4 \%$. Esta última variável revela um comportamento bastante mais constante, no que respeita à sua distribuição, comparativamente às restantes três. 


\begin{tabular}{|c|c|c|c|c|c|}
\hline & Idade & $\begin{array}{c}\text { Leitura de } \\
\text { Livros }\end{array}$ & $\begin{array}{c}\text { Leitura de } \\
\text { Jornais }\end{array}$ & $\begin{array}{c}\text { Leitura de } \\
\text { Revistas }\end{array}$ & $\begin{array}{c}\text { Leitura de } \\
\text { Enciclopédias }\end{array}$ \\
\hline & Média & 3,0000 & 1,5000 & 2,0000 & 3,5000 \\
\hline $\begin{array}{l}{[20 \text { a } 30]} \\
a n o s\end{array}$ & $\mathbf{N}$ & 2 & 2 & 2 & 2 \\
\hline & Desvio Padrão & 1,41421 & ,70711 &, 00000 & ,70711 \\
\hline & Média & 2,0000 & 1,8667 & 2,0667 & 3,4000 \\
\hline $\begin{array}{l}{\left[\begin{array}{ll}30 & \mathrm{a} \\
\operatorname{anos}\end{array}\right.} \\
\text { anos }\end{array}$ & $\mathbf{N}$ & 15 & 15 & 15 & 10 \\
\hline & Desvio Padrão & 1,30931 & 63994 & 88372 & 96609 \\
\hline & Média & 2,1591 & 1,5952 & 2,3000 & 3,2353 \\
\hline $\begin{array}{l}{\left[\begin{array}{ll}40 & \text { a } \\
\operatorname{annos}\end{array}\right.} \\
\text { and }\end{array}$ & $\mathbf{N}$ & 44 & 42 & 40 & 34 \\
\hline & Desvio Padrão & 1,14004 & ,76699 & ,85335 & 1,04617 \\
\hline & Média & 1,7273 & 1,6308 & 2,4167 & 3,1316 \\
\hline$\left[\begin{array}{ll}1900 \mathrm{a} & 00\end{array}\right]$ & $\mathbf{N}$ & 66 & 65 & 60 & 38 \\
\hline & Desvio Padrão & 1,07482 & ,62673 & ,88857 & 1,14304 \\
\hline & Média & 3,0000 & 1,0000 & & \\
\hline$>60$ anos & $\mathbf{N}$ & 1 & 1 & & \\
\hline & Desvio Padrão & . & . & & \\
\hline & Média & 1,9375 & 1,6400 & 2,3248 & 3,2143 \\
\hline Total & $\mathbf{N}$ & 128 & 125 & 117 & 84 \\
\hline & Desvio Padrão & 1,14156 & ,67680 & ,86929 & 1,06501 \\
\hline
\end{tabular}

Tabela 2: Médias e respetivos Desvio Padrão para a frequência de leitura de Livros, Jornais, Revistas e Enciclopédias relativamente à Idade

Se tivermos em consideração a variável Habilitações Académicas, podemos constatar que existe uma grande dispersão de dados, o que torna algumas categorias quase residuais e, por isso, mesmo difícil de retirar qualquer ilação. Porém, ainda assim, podemos observar na tabela 3 que os possuidores de mestrado, com 1.45, são os que declaram ler com maior frequência jornais, em claro antagonismo com os possuidores de Licenciatura em $2^{\circ}$ Ciclo do Ensino Básico na variante Ciências e Matemática com apenas 2.33. No entanto, este último grupo é aquele, no que se refere à leitura de livros, que apresenta maior frequência, com uma média de 1.33. Ainda relativamente a este aspeto, o grupo que incorpora os portadores de Licenciatura em $1^{\circ}$ Ciclo do Ensino Básico é o que tem menores índices de leitura de livros com 2.24.

No computo geral destas variáveis, podemos sintetizar a informação relativa a mulheres as quais revelam maior leitura de livros, enquanto que os homens preferem os jornais. São também os mais velhos que mais leem livros, existindo indícios que os mais novos preferem dedicar o seu tempo a jornais e revistas, sendo que o mais alto grau académico, considerado na presente análise, prefere ler jornais em detrimento de livros. Ora, perante estes dados entendemos que há alguns aspetos que nos merecem alguma reflexão. No passado, havia maior propensão para a leitura de livros. No

ISL, vol. 4, 2015, págs. $25-50$ ISNN: $2340-8685$
Sardinha, M. G., Azevedo, F. J. y Rato, R (2015): Promoção da leitura na escola portuguesa: metodologias e crenças dos professores do Ensino Básico, Investigaciones Sobre Lectura, 4, 25-50. 
presente são as revistas e os jornais os mais procurados. Ainda assim, o facto de a leitura de livros ser feita por uma classe etária mais elevada e, no estudo, detentora de habilitações conseguidas como reclassificações, não pode deixar de nos interrogar sobre o que se passa no sistema de ensino português. A leitura para «se manter informado» ultrapassa a leitura que nos traz cultura e conhecimento.

\begin{tabular}{|c|c|c|c|c|c|}
\hline Habilitações Aca & démicas & $\begin{array}{l}\text { Leitura de } \\
\text { Livros }\end{array}$ & $\begin{array}{c}\text { Leitura de } \\
\text { Jornais }\end{array}$ & $\begin{array}{l}\text { Leitura de } \\
\text { Revistas }\end{array}$ & $\begin{array}{c}\text { Leitura de } \\
\text { Enciclopédias }\end{array}$ \\
\hline Bacharelato & $\begin{array}{l}\text { Média } \\
\text { N } \\
\text { Desvio Padrão }\end{array}$ & $\begin{array}{c}1,8286 \\
35 \\
1,17538\end{array}$ & $\begin{array}{c}1,5882 \\
34 \\
, 49955\end{array}$ & $\begin{array}{c}2,4839 \\
31 \\
, 99569\end{array}$ & $\begin{array}{c}3,5500 \\
20 \\
, 75915\end{array}$ \\
\hline $\begin{array}{c}\text { Bacharelato } \\
+ \\
\text { Complementos }\end{array}$ & $\begin{array}{l}\text { Média } \\
\text { N } \\
\text { Desvio Padrão }\end{array}$ & $\begin{array}{c}1,8868 \\
53 \\
1,03144\end{array}$ & $\begin{array}{c}1,6346 \\
52 \\
, 71480\end{array}$ & $\begin{array}{c}2,3000 \\
50 \\
, 90914\end{array}$ & $\begin{array}{c}3,1081 \\
37 \\
1,17340\end{array}$ \\
\hline $\begin{array}{l}\text { Licenciatura em } 1^{\circ} \text { Ciclo } \\
\text { do Ensino Básico }\end{array}$ & $\begin{array}{l}\text { Média } \\
\text { N } \\
\text { Desvio Padrão }\end{array}$ & $\begin{array}{c}2,2353 \\
17 \\
1,30045\end{array}$ & $\begin{array}{c}1,5625 \\
16 \\
, 62915\end{array}$ & $\begin{array}{c}2,3077 \\
13 \\
, 75107\end{array}$ & $\begin{array}{c}2,3333 \\
9 \\
1,22474\end{array}$ \\
\hline $\begin{array}{c}\text { Licenciatura em } 2^{\circ} \text { Ciclo } \\
\text { do Ensino Básico - } \\
\text { variante } \\
\text { Português/Francês }\end{array}$ & $\begin{array}{l}\text { Média } \\
\text { N } \\
\text { Desvio Padrão }\end{array}$ & $\begin{array}{c}1,8750 \\
8 \\
1,12599\end{array}$ & $\begin{array}{c}2,0000 \\
8 \\
1,06904\end{array}$ & $\begin{array}{c}2,3750 \\
8 \\
, 74402\end{array}$ & $\begin{array}{c}3,0000 \\
6 \\
1,09545\end{array}$ \\
\hline $\begin{array}{l}\text { Licenciatura em } 2^{\circ} \text { Ciclo } \\
\text { do Ensino Básico - } \\
\text { variante Educação Física }\end{array}$ & $\begin{array}{l}\text { Média } \\
\text { N } \\
\text { Desvio Padrão }\end{array}$ & $\begin{array}{c}1,0000 \\
1\end{array}$ & $\begin{array}{c}2,0000 \\
1 \\
.\end{array}$ & $\begin{array}{c}2,0000 \\
1 \\
.\end{array}$ & $\begin{array}{c}3,0000 \\
1 \\
.\end{array}$ \\
\hline $\begin{array}{c}\text { Licenciatura em } 2^{\circ} \text { Ciclo } \\
\text { do Ensino Básico - } \\
\text { variante Ciências e } \\
\text { Matemática }\end{array}$ & $\begin{array}{l}\text { Média } \\
\text { N } \\
\text { Desvio Padrão }\end{array}$ & $\begin{array}{c}1,3333 \\
3 \\
, 57735\end{array}$ & $\begin{array}{c}2,3333 \\
3 \\
, 57735\end{array}$ & $\begin{array}{c}1,6667 \\
3 \\
\\
, 57735\end{array}$ & $\begin{array}{c}4,0000 \\
2 \\
, 00000\end{array}$ \\
\hline Mestrado & $\begin{array}{l}\text { Média } \\
\text { N } \\
\text { Desvio Padrão }\end{array}$ & $\begin{array}{c}2,3636 \\
11 \\
1,43337\end{array}$ & $\begin{array}{c}1,4545 \\
11 \\
, 68755\end{array}$ & $\begin{array}{c}2,1818 \\
11 \\
, 60302\end{array}$ & $\begin{array}{c}3,7778 \\
9 \\
, 44096\end{array}$ \\
\hline
\end{tabular}




\begin{tabular}{|c|c|c|c|c|c|}
\hline \multirow{3}{*}{ Total } & Média & 1,9375 & 1,6400 & 2,3248 & 3,2143 \\
\hline & $\mathbf{N}$ & 128 & 125 & 117 & 84 \\
\hline & Desvio Padrão & 1,14156 & ,67680 & ,86929 & 1,06501 \\
\hline
\end{tabular}

Tabela 3: Médias e respetivos Desvio Padrão para a frequência de leitura de Livros, Jornais, Revistas e

Enciclopédias relativamente às Habilitações Académicas

Passando à análise da distribuição dos dados empíricos referentes à questão que confrontava os inquiridos com o uso da Biblioteca Escolar / Centro de Recursos Educativos (BE/CRE) no âmbito das atividades letivas relacionadas com a aprendizagem da Língua Portuguesa (gráfico 5), estes apresentam-se-nos com uma distribuição algo assimétrica, em face do peso manifestado pelas duas categorias que agrupam a menor frequência deste tipo de atividade. Concretizando, dir-se-á que a categoria "nunca" tem $17.9 \%$ das respostas e a categoria que reúne os que recorreram 1 a 2 vezes atinge os $49.3 \%$, sendo que o somatório de ambas atinge $67.2 \%$, isto é, cerca de $2 / 3$ dos inquiridos revela uma frequência baixa ou mesmo nula, deste tipo de recurso.

Por outro lado, considerando as duas restantes categorias, as que reúnem os que apresentam maior frequência, constata-se que de entre 3 a 4 vezes foram $19.4 \%$ e 5, ou mais vezes, apenas $13.4 \%$ dos inquiridos. No plano da distribuição dos dados, tendo como eixo analítico o grupo sexual de pertença, podemos verificar que existe uma clara tendência de maior frequência de uso por parte do grupo feminino, comparativamente ao seu congénere masculino.

Esta constatação é sustentada pela observação da média obtida por ambos os grupos, sendo posteriormente corroborada por um teste de hipóteses. Na ótica da construção que tem vindo a ser feita (com a fraca leitura de livros), não nos admira pois a pouca frequência em relação às $\mathrm{BE} / \mathrm{CREs}$ que têm vindo a desempenhar um papel relevante, com o desenvolvimento de projetos assinaláveis e reconhecidos em todas as escolas. Nesta perspetiva, o facto de os professores não terem relacionamento com as $\mathrm{BE} / \mathrm{CREs}$ parece-nos grave.

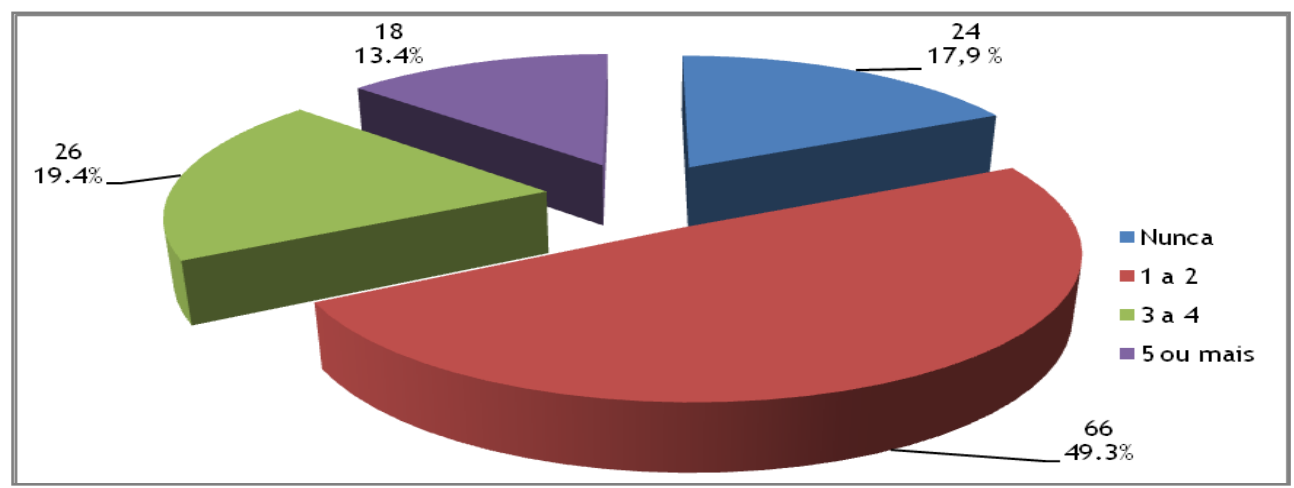

Gráfico 5: Frequência de uso BE/CRE com alunos no último mês

ISL, vol. 4, 2015, págs. $25-50$ ISNN: 2340-8685
Sardinha, M. G., Azevedo, F. J. y Rato, R (2015): Promoção da leitura na escola portuguesa: metodologias e crenças dos professores do Ensino Básico, Investigaciones Sobre Lectura, 4, 25-50. 
Retomando o assunto sobre o grau de frequência de uso da BE/CRE, podemos dizer que ainda assim verificamos que os homens obtêm uma média de 2.04, e, em contrapartida, as mulheres atingem os 2.34. Tal como já tivemos oportunidade de verificar, também o teste de hipóteses para as médias independentes corrobora esta conclusão, dado que o valor de significância deste teste não excede os 0.01 , o que nos leva a rejeitar a hipótese nula, que afirma que as médias são iguais. Nesta linha de raciocínio, efetuou-se semelhante procedimento, mas para a idade. Neste sentido, pudemos aferir que é o grupo dos [50 aos 60] anos que apresenta maior média de frequência da BE/CRE, com 2.37, um pouco superior ao grupo etário anterior [40 aos 50] que não vai além 2.22. Esta ilação é confirmada também pelo teste de hipótese, que confirma a existência de diferenças estatística significativas entre ambas as amostras. Os restantes grupos etários foram excluídos ou por terem um número muito reduzido de elementos ou porque as suas respetivas médias eram bastante abaixo das duas mencionadas.

No que se refere à variável "anos de serviço", verificamos que é o grupo com maior longevidade profissional o que apresenta a maior média, registando 2.36, seguido do grupo [20 a 30] anos de serviço com 2,23. Porém, realizado o teste de hipóteses, verificamos que, em termos inferenciais, isto é, ao nível do universo, esta diferença não é extrapolável, sendo apenas uma idiossincrasia desta amostra (sig. 0.39). Finalmente, considerando a variável "habilitações académicas", verificamos que são os dois primeiros grupos os que têm maior média com respetivamente 2.17 e 2.46 . De fato, esta diferença, ao nível da estatística de inferência, diz-nos que existem diferenças significativas entre ambos os grupos, obtendo-se um nível de significância de 0.04. Embora já tivéssemos feito uma alusão à falta de frequência da BE/CRE, o facto de serem as mulheres a frequentá-la não nos parece relevante. Importa, pois, salientar que a assiduidade de uns e outros é baixa.

O terceiro grupo do inquérito por questionário tem o seu início com uma bateria de questões que confrontam o inquirido com uma multiplicidade de potenciais estratégias de dinamização do ensino e da aprendizagem, mormente da escrita. Neste sentido, numa primeira e genérica abordagem aos dados contidos no gráfico 6, podemos dizer que existe uma larga maioria de docentes inquiridos que declara estabelecer parcerias para desenvolver as competências relacionadas com a escrita. Concretizando, são $88.1 \%$ dos inquiridos que afirmam utilizar este tipo de procedimentos, contra apenas $11.9 \%$. 


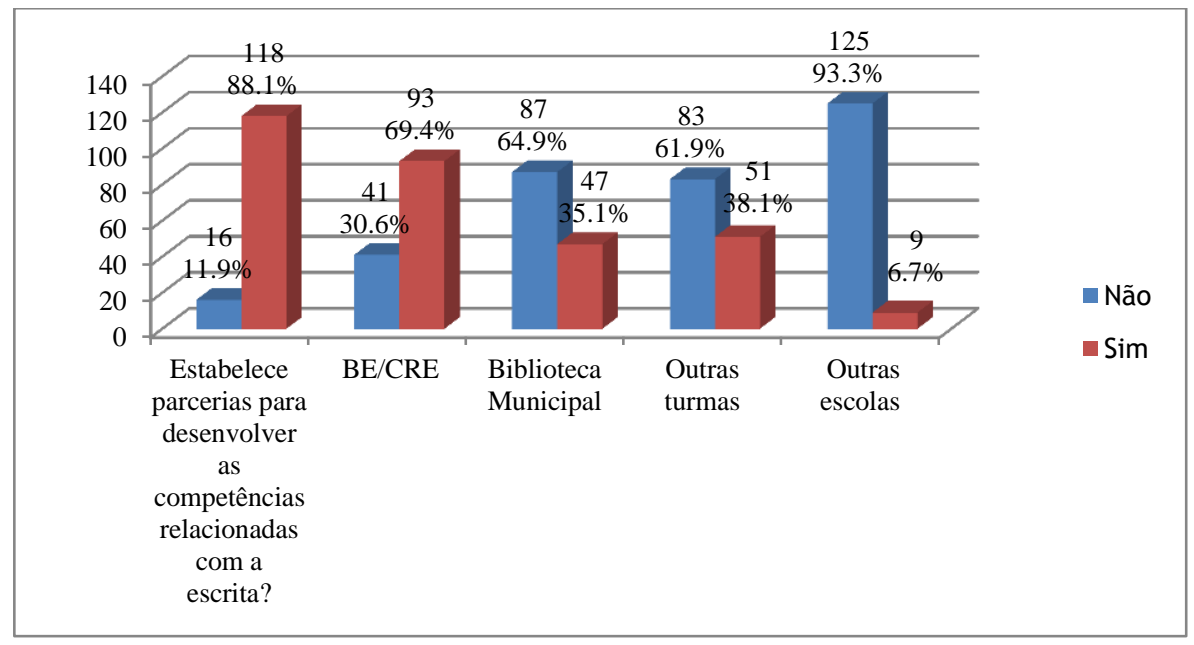

Gráfico 6: Estabelecimento de parcerias

No entanto, se procedermos ao aprofundamento do referido gráfico, verificamos que apenas uma das opções, no caso particular o recurso a BE/CRE, obtém um nível de aprovação substancialmente elevado, isto é, maioritário, em face dos restantes que invariavelmente obtêm valores minoritários de uso. São os casos do recurso a Bibliotecas Municipais, em que apenas 35.1\% refere estabelecer uma parceria, na linha do uso de parcerias com outras turmas (38.1\%). Finalmente, o recurso ao estabelecimento de parcerias com outras escolas, na qual a distribuição $93.3 \%$ de não adesão.

A este tipo de procedimento parece aderir com muito maior intensidade o grupo de docentes do género feminino, em face dos dados apresentados na tabela 4, onde podemos observar constantemente média superior na mulher, no que respeita ao estabelecimento de parcerias, relativamente ao grupo masculino. Estas diferenças assumem contornos substanciais, dado que superam quase sempre uma décima.

\begin{tabular}{|c|c|c|c|c|c|c|}
\hline \multicolumn{2}{|c|}{ Género } & $\begin{array}{c}\text { Estabelece parcerias para } \\
\text { desenvolver as competências } \\
\text { relacionadas com a escrita? }\end{array}$ & BE/CRE & $\begin{array}{l}\text { Biblioteca } \\
\text { Municipal }\end{array}$ & $\begin{array}{l}\text { Outras } \\
\text { turmas }\end{array}$ & $\begin{array}{c}\text { Outras } \\
\text { Escolas }\end{array}$ \\
\hline \multirow{3}{*}{ Masculino } & Média & ,7083 & ,5417 & ,2500 & ,2500 &, 0000 \\
\hline & $\mathbf{N}$ & 24 & 24 & 24 & 24 & 24 \\
\hline & $\begin{array}{l}\text { Desvio } \\
\text { Padrão }\end{array}$ & ,46431 & ,50898 & ,44233 & ,44233 & ,00000 \\
\hline \multirow{3}{*}{ Feminino } & Média & ,9182 & ,7273 & ,3727 & ,4091 & ,0818 \\
\hline & $\mathbf{N}$ & 110 & 110 & 110 & 110 & 110 \\
\hline & $\begin{array}{l}\text { Desvio } \\
\text { Padrão }\end{array}$ & ,27534 & ,44740 & ,48574 & ,49392 & ,27534 \\
\hline
\end{tabular}

ISL, vol. 4, 2015, págs. $25-50$ ISNN: 2340-8685
Sardinha, M. G., Azevedo, F. J. y Rato, R (2015): Promoção da leitura na escola portuguesa: metodologias e crenças dos professores do Ensino Básico, Investigaciones Sobre Lectura, 4, 25-50. 


\begin{tabular}{|c|c|c|c|c|c|c|}
\hline \multirow{3}{*}{ Total } & Média & ,8806 & 6940 &, 3507 & ,3806 & ,0672 \\
\hline & $\mathbf{N}$ & 134 & 134 & 134 & 134 & 134 \\
\hline & $\begin{array}{l}\text { Desvio } \\
\text { Padrão }\end{array}$ & ,32548 & ,46255 & 47899 & ,48736 & ,25125 \\
\hline
\end{tabular}

Tabela 4: Médias por Género e Estabelecimento de parcerias para desenvolver as competências relacionadas com a escrita

Dados interessantes são aqueles que nos são oferecidos pela tabela 6, que resulta do cruzamento do conjunto de questões em análise, relacionadas com o estabelecimento de parecerias e a variável idade. Nesta linha, ter-se-á de frisar que se deteta um maior uso deste tipo de recurso, por parte do grupo etário dos [50 a 60] anos. Porém, existe uma exceção, quando consideramos, única e exclusivamente, o recurso a BE/CRE, em que este grupo se vê suplantado pelo grupo [30 a 40] anos, isto é, 0.71 e 0.87 respetivamente. Este fato, estatisticamente observável, poder-se-á ficar a dever a uma menor proximidade deste grupo mais velho, relativamente às novas tecnologias, uma última nota, para sublinhar os baixos valores obtidos pelo grupo etário intermédio [40 a 50] anos. Contudo, os dados, em termos gerais, indiciam haver uma disjunção pronunciada das respostas afirmativas, e, posteriormente, naquelas em que esse recurso é efetivado.

\begin{tabular}{|c|c|c|c|c|c|c|}
\hline \multicolumn{2}{|r|}{ Idade } & $\begin{array}{l}\text { Estabelece parcerias } \\
\text { para desenvolver as } \\
\text { competências } \\
\text { relacionadas com a } \\
\text { escrita? }\end{array}$ & BE/CRE & $\begin{array}{l}\text { Biblioteca } \\
\text { Municipal }\end{array}$ & $\begin{array}{l}\text { Outras } \\
\text { turmas }\end{array}$ & $\begin{array}{l}\text { Outras } \\
\text { Escolas }\end{array}$ \\
\hline \multirow{3}{*}{$\begin{array}{l}{[20 \text { a } 30]} \\
\text { anos }\end{array}$} & Média &, 5000 & ,5000 & ,0000 & ,0000 &, 0000 \\
\hline & $\mathbf{N}$ & 2 & 2 & 2 & 2 & 2 \\
\hline & Desvio Padrão & ,70711 & ,70711 & ,00000 & ,00000 & ,00000 \\
\hline \multirow{3}{*}{$\begin{array}{l}{[30 \text { a } 40]} \\
\text { anos }\end{array}$} & Média & ,9333 & ,8667 & ,3333 & ,4000 & ,0000 \\
\hline & $\mathbf{N}$ & 15 & 15 & 15 & 15 & 15 \\
\hline & Desvio Padrão & ,25820 & ,35187 & , 48795 & ,50709 & ,00000 \\
\hline \multirow{3}{*}{$\begin{array}{c}{[40 \text { a } 50]} \\
\text { anos }\end{array}$} & Média & ,8043 & ,6304 & ,3696 & ,3043 & ,0435 \\
\hline & $\mathbf{N}$ & 46 & 46 & 46 & 46 & 46 \\
\hline & Desvio Padrão & 40109 & ,48802 & ,48802 & ,46522 & ,20618 \\
\hline \multirow{3}{*}{$\begin{array}{c}{[50 \text { a } 60]} \\
\quad \operatorname{anos}\end{array}$} & Média & ,9429 & ,7143 & ,3571 & ,4429 & , 1000 \\
\hline & $\mathbf{N}$ & 70 & 70 & 70 & 70 & 70 \\
\hline & Desvio Padrão & 23379 & ,45502 & ,48262 & ,50031 & ,30217 \\
\hline \multirow{3}{*}{$>60$ anos } & Média & ,0000 & ,0000 & ,0000 & ,0000 & ,0000 \\
\hline & $\mathbf{N}$ & 1 & 1 & 1 & 1 & 1 \\
\hline & Desvio Padrão & . & . & . & . & . \\
\hline
\end{tabular}




\begin{tabular}{|cc|c|c|c|c|c|}
\hline \multirow{4}{*}{ Total } & Média &, 8806 &, 6940 &, 3507 &, 3806 &, 0672 \\
& $\mathbf{N}$ & 134 & 134 & 134 & 134 & 134 \\
& Desvio Padrão &, 32548 &, 46255 &, 47899 &, 48736 &, 25125 \\
\hline
\end{tabular}

Tabela 5: Médias por Idade e Estabelecimento de parcerias para desenvolver as competências relacionadas com a escrita

Estas mesmas tendências constatam-se quando realizada a mesma operação em relação aos anos de serviço. Quanto ao peso preditivo que a variável habilitações académicas poderia ter na maior ou menor adesão, podemos retirar a ilação de que são os dois grupos dos extremos como o Bacharelato e o Mestrado. Nas restantes categorias, nomeadamente nas de licenciatura de $2^{\circ}$ ciclo, nas suas várias vertentes, o número de inquiridos é quase residual não tendo o valor suficiente para se retirarem dados assertivos.

Perante os dados obtidos, continua-se a observar o interesse por este tipo de procedimentos da parte dos que pertencem a uma classe etária mais elevada. A interrogação que levantámos no início sobre o que se passa no sistema de ensino português tem novamente aqui a sua expressão. De facto, a classe mais nova parece manter uma postura mais indiferente no que diz respeito à necessidade de se estabelecerem parcerias.

\begin{tabular}{|c|c|c|c|c|c|c|}
\hline \multicolumn{2}{|c|}{ Habilitações Académicas } & $\begin{array}{c}\text { Estabelece parcerias para } \\
\text { desenvolver as } \\
\text { competências } \\
\text { relacionadas com a } \\
\text { escrita? }\end{array}$ & BE/CRE & $\begin{array}{l}\text { Biblioteca } \\
\text { Municipal }\end{array}$ & $\begin{array}{l}\text { Outras } \\
\text { turmas }\end{array}$ & $\begin{array}{l}\text { Outras } \\
\text { escolas }\end{array}$ \\
\hline \multirow{3}{*}{ Bacharelato } & Média & ,9444 &, 7500 & ,3889 & ,3056 &, 1111 \\
\hline & $\mathbf{N}$ & 36 & 36 & 36 & 36 & 36 \\
\hline & $\begin{array}{l}\text { Desvio } \\
\text { Padrão }\end{array}$ & ,23231 & ,43916 & ,49441 & ,46718 & ,31873 \\
\hline \multirow{3}{*}{$\begin{array}{c}\text { Bacharelato } \\
+ \\
\text { Complementos }\end{array}$} & Média &, 8772 & ,6491 & ,3860 &, 5088 & ,0351 \\
\hline & $\mathbf{N}$ & 57 & 57 & 57 & 57 & 57 \\
\hline & $\begin{array}{l}\text { Desvio } \\
\text { Padrão }\end{array}$ & ,33113 & ,48149 & ,49115 &, 50437 &, 18564 \\
\hline \multirow{3}{*}{$\begin{array}{c}\text { Licenciatura em } 1^{\circ} \\
\text { Ciclo do Ensino } \\
\text { Básico }\end{array}$} & Média & ,6667 & ,4444 & ,2222 &, 2222 &, 0556 \\
\hline & $\mathbf{N}$ & 18 & 18 & 18 & 18 & 18 \\
\hline & $\begin{array}{l}\text { Desvio } \\
\text { Padrão }\end{array}$ & ,48507 &, 51131 & ,42779 & ,42779 & ,23570 \\
\hline \multirow{2}{*}{$\begin{array}{c}\text { Licenciatura em } 2^{\circ} \\
\text { Ciclo do Ensino } \\
\text { Básico - }\end{array}$} & Média & 1,0000 & 1,0000 &, 1250 &, 5000 &, 1250 \\
\hline & $\mathbf{N}$ & 8 & 8 & 8 & 8 & 8 \\
\hline
\end{tabular}

ISL, vol. 4, 2015, págs. $25-50$ ISNN: 2340-8685
Sardinha, M. G., Azevedo, F. J. y Rato, R (2015): Promoção da leitura na escola portuguesa: metodologias e crenças dos professores do Ensino Básico, Investigaciones Sobre Lectura, 4, 25-50. 


\begin{tabular}{|c|c|c|c|c|c|c|}
\hline Português/Francês & $\begin{array}{l}\text { Desvio } \\
\text { Padrão }\end{array}$ &, 00000 & ,00000 & ,35355 &, 53452 & ,35355 \\
\hline $\begin{array}{c}\text { Licenciatura em } 2^{\circ} \\
\text { Ciclo do Ensino } \\
\text { Básico -Educação } \\
\text { Física }\end{array}$ & $\begin{array}{l}\text { Média } \\
\text { N } \\
\text { Desvio } \\
\text { Padrão }\end{array}$ & $\begin{array}{c}1,0000 \\
1 \\
.\end{array}$ & $\begin{array}{c}1,0000 \\
1 \\
.\end{array}$ & $\begin{array}{c}1,0000 \\
1 \\
.\end{array}$ & $\begin{array}{c}1,0000 \\
1\end{array}$ & $\begin{array}{c}, 0000 \\
1 \\
.\end{array}$ \\
\hline $\begin{array}{c}\text { Licenciatura em } 2^{\circ} \\
\text { Ciclo do Ensino } \\
\text { Básico - } \\
\text { Ciências/Matemática }\end{array}$ & $\begin{array}{l}\text { Média } \\
\text { N } \\
\text { Desvio } \\
\text { Padrão }\end{array}$ & $\begin{array}{c}1,0000 \\
3 \\
, 00000\end{array}$ & $\begin{array}{c}1,0000 \\
3 \\
, 00000\end{array}$ & $\begin{array}{c}, 6667 \\
3 \\
, 57735\end{array}$ & $\begin{array}{c}, 0000 \\
3 \\
, 00000\end{array}$ & $\begin{array}{c}, 0000 \\
3 \\
, 00000\end{array}$ \\
\hline Mestrado & $\begin{array}{l}\text { Média } \\
\text { N } \\
\text { Desvio } \\
\text { Padrão }\end{array}$ & $\begin{array}{c}, 9091 \\
11 \\
, 30151\end{array}$ & $\begin{array}{c}, 8182 \\
11 \\
, 40452\end{array}$ & $\begin{array}{c}, 2727 \\
11 \\
, 46710\end{array}$ & $\begin{array}{c}, 1818 \\
11 \\
, 40452\end{array}$ & $\begin{array}{c}, 0909 \\
11 \\
, 30151\end{array}$ \\
\hline Total & $\begin{array}{l}\text { Média } \\
\text { N } \\
\text { Desvio } \\
\text { Padrão }\end{array}$ & $\begin{array}{c}, 8806 \\
134 \\
, 32548\end{array}$ & $\begin{array}{c}, 6940 \\
134 \\
, 46255\end{array}$ & $\begin{array}{c}, 3507 \\
134 \\
, 47899\end{array}$ & $\begin{array}{c}, 3806 \\
134 \\
, 48736\end{array}$ & $\begin{array}{c}, 0672 \\
134 \\
, 25125\end{array}$ \\
\hline
\end{tabular}

Tabela 6: Estabelece parcerias para desenvolver as competências relacionadas com a escrita?

O gráfico 7 sintetiza os dados obtidos com a aplicação da segunda bateria de questões, onde o objetivo era traçar um esboço dos usos e aplicações do estabelecimento de parcerias. Assim, aos inquiridos era solicitado que, de entre um conjunto de seis situações, selecionassem aquelas que já realizaram, ou que realizam com maior frequência. Num plano genérico, podemos, desde logo, considerar, que existem, ao nível das respostas dadas pelos inquiridos, dois grandes grupos. Por um lado, as três primeiras categorias que obtêm todas elas avaliações maioritariamente positivas, isto é, o "Incentivar os alunos a ir à BE/CRE ler e requisitar livros relacionados com as temáticas abordadas" com 62.7\%, mas também o "assistir a sessões de leitura" com $56 \%$. Porém, o valor mais expressivo é obtido pelo parâmetro que afirma "requisitar livros para o domicílio", com $64.9 \%$.

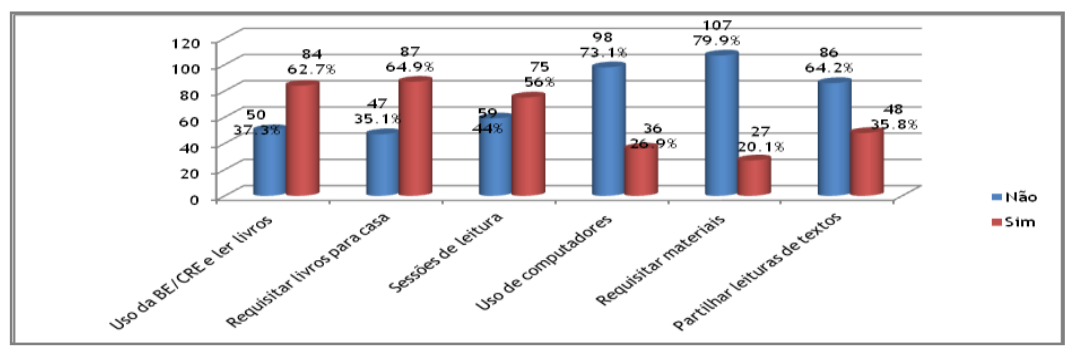

Gráfico 7: Concretização das parcerias 
Por outro lado, um segundo conjunto é composto pelas dimensões de que os inquiridos declararam não fazer ou fazê-lo com pouca frequência. São partes deste segundo grupo, "aceder aos computadores para realizar trabalhos", com apenas $26.9 \%$, a declarar já o ter feito, no contexto do estabelecimento de parcerias, mas também é o caso de "partilhar leituras de textos" com 35.8\% e, finalmente, a menos representativa, segundo os dados recolhidos, diz respeito "requisitar materiais para a sala de aula" com apenas $20.1 \%$ a referir já terem implementado esta estratégia.

A nota dominante para os dados contidos no gráfico 8 diz respeito ao claro e avassalador domínio das respostas afirmativas, relativamente à frequência de requisição de livros na BE/CRE. Concretizando, são apenas 14, isto é, $10.4 \%$ dos inquiridos os que afirmam que os seus alunos não requisitam qualquer livro. Por seu lado, são $89.6 \%$ os que afirmam, que os alunos da sua turma requisitam livros da BE/CRE. A disjunção entre os dados é tão grande que invalida uma análise mais aprofundada da ou das razões que sustentam esses resultados.

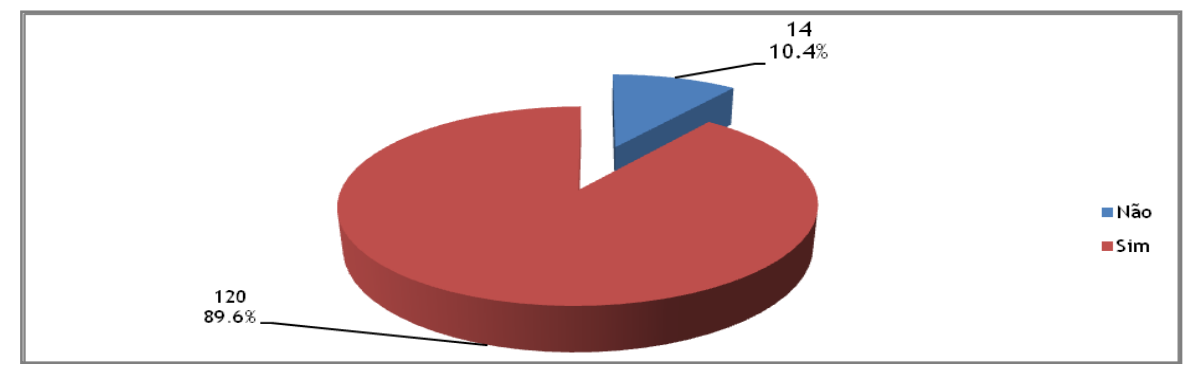

Gráfico 8: Requisição de livros na BE/CRE

Relativamente à preponderância que o nível de habilitações académicas pode desempenhar, na maior ou menor frequência, no que diz respeito à requisição de livros, podemos verificar que é entre o grupo dos portadores de Licenciatura $1^{\circ}$ Ciclo do Ensino Básico que temos a melhor média com 1, isto é, a totalidade do grupo respondeu que os seus alunos recorrem à biblioteca para requisitar livros, contraposição com os de mestrado, com 0.82. Esta análise exclui todos os grupos de habilitações que obtiveram valores inferiores a 10 elementos, dada a reduzida dimensão da amostra e a sua pertinência para a presente análise. Retomamos, aqui o raciocínio que temos vindo a delinear. De fato, embora as parcerias com as BE/CREs sejam reduzidas os professores licenciados promovem os hábitos de leitura ao motivarem os alunos para a requisição de livros. Parece existir aqui alguma contradição que nos leva a refletir, enquanto docentes envolvidos na formação de professores, sobre temas que frequentemente se debatem acerca do comodismo instalado que necessita urgentemente de mudança.

Já no plano da frequência com que o fazem, teremos, necessariamente, de frisar a média obtida pelo grupo portador de Bacharelato, com 1.58, a mais próxima da frequência semanal. Para rematar a presente bateria de questões, diríamos que os homens declaram que os seus alunos recorrem à biblioteca para requisitar livros,

ISL, vol. 4, 2015, págs. 25-50 ISNN: 2340-8685
Sardinha, M. G., Azevedo, F. J. y Rato, R (2015): Promoção da leitura na escola portuguesa: metodologias e crenças dos professores do Ensino Básico, Investigaciones Sobre Lectura, 4, 25-50. 
tendência também verificada quando analisamos a frequência com que o fazem. Quanto à idade, são os dos [40 a 50] anos que declaram, em maior proporção. Porém, é no grupo dos [30 a 40] anos que verificamos maior frequência a este recurso. Já nos anos de serviço, é o grupo dos [20 a 30] anos e os seus alunos aqueles que mais recorrem à biblioteca. Ainda assim, em termos de frequência, é o grupo dos [10 a 20] anos que o faz com mais regularidade. Quanto às habitações académicas, podemos observar que é no grupo com Licenciatura no $1^{\circ}$ Ciclo do Ensino Básico que declaram maior recurso a este tipo de estratégia de aprendizagem. No entanto, é no bacharelato que encontramos a maior frequência.

Com a quarta e última bateria de questões do terceiro grupo que compõe o inquérito por questionário, pretendíamos sobretudo aferir acerca dos variados e multifacetados usos que se podem realizar, potencialmente dos livros, em contexto de sala de aula. Numa abordagem genérica dir-se-á que o livro se constitui como uma privilegiada tecnologia, no processo de aprendizagem, desde os ciclos iniciais do percurso escolar. Esta alusão surge num contexto de interpretação dos dados contidos no gráfico 11, em que, desde logo, podemos observar que apenas um dos inquiridos declara não recorrer a este recurso, que é o livro. No que se refere às suas mais variadas aplicabilidades, podemos, desde logo, afirmar que, apenas uma das seis aplicabilidades obtém um registo negativo isto é, a "elaboração de esquemas ou diagramas" surge com $68.7 \%$ dos inquiridos a declarar não a utilizar. Por outro lado, são apenas $31.3 \%$ que afirmam fazê-lo.

Este aspeto merece, em nossa opinião, um destaque que remete para a capacidade que os professores têm de ir para além do manual. De facto, cada vez mais o manual deixou de ser o único mediador das práticas pedagógicas dando lugar a outros livros e consequentemente a outro tipo de olhares.

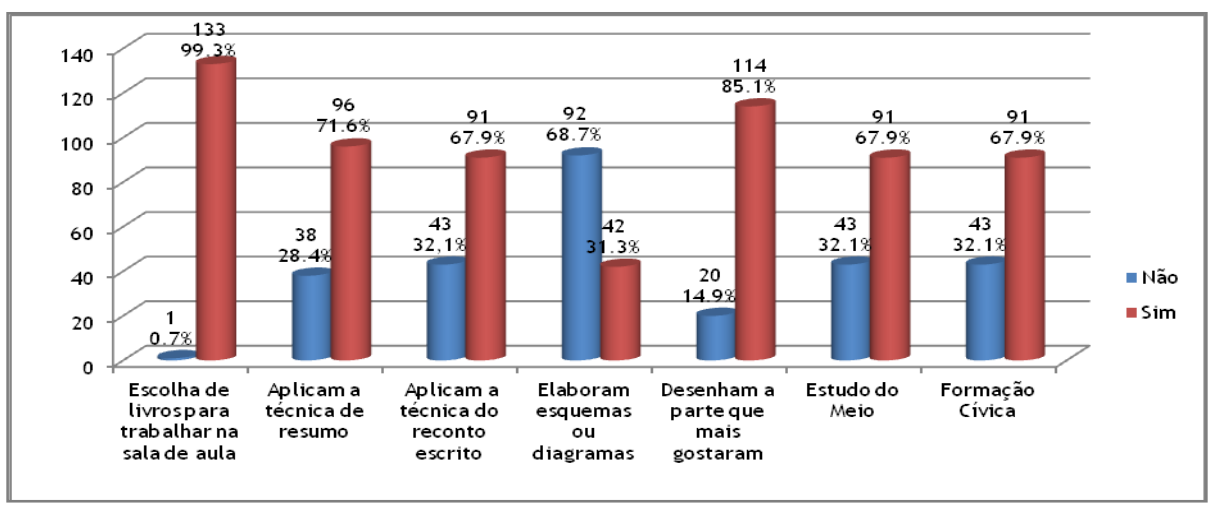

Gráfico 9: Escolha de Livros para trabalhar

De entre os indicadores com maiores níveis de aplicação, teremos, necessariamente, de destacar os que afirmam que "desenham a parte que mais gostaram" com $85.1 \%$ a dizer que o faz, seguida os que "aplicam a técnica de resumo" 
com 71.6\%. Finalmente, e com o mesmo valor (67.9\%), encontramos as restantes três. Deste modo, o livro indicia desempenhar um papel nevrálgico no seio da sala de aula.

Passando à análise destas variáveis, procedendo ao cruzamento com as designadas variáveis sociodemográficas, e, começando, desde já, pelo estabelecimento de uma tentativa de interpretação do único caso que tem um registo, que designaremos como "negativo", para aludir à maioria de não utilizações, podemos verificar que é entre o grupo masculino que a média é menor, com apenas 0.21 , já que no grupo feminino esta ascende 0.34 , tal como é observável na tabela 7 relativamente à elaboração de esquemas e/ou diagramas. Esta constatação é, desde logo, confirmada, ao nível da estatística de inferência, com a realização de um teste de hipóteses, onde obtivemos um nível de significância de cerca 0.003 , o que, em termos práticos, nos permite rejeitar a hipótese nula, que afirma a igualdade das médias de ambos os grupos. As médias de homens e mulheres são ao nível inferencial, diferentes, muito particularmente, neste aspeto.

\begin{tabular}{|c|c|c|c|c|c|c|c|c|}
\hline \multicolumn{2}{|c|}{ Género } & $\begin{array}{c}\text { Costuma } \\
\text { escolher } \\
\text { livros para } \\
\text { trabalhar, } \\
\text { na sala de } \\
\text { aula }\end{array}$ & \begin{tabular}{|c|} 
Os \\
alunos \\
aplicam \\
a técnica \\
de \\
resumo
\end{tabular} & $\begin{array}{c}\text { Os alunos } \\
\text { aplicam a } \\
\text { técnica do } \\
\text { reconto } \\
\text { escrito }\end{array}$ & $\begin{array}{c}\text { Os alunos } \\
\text { elaboram } \\
\text { esquemas } \\
\text { ou } \\
\text { diagramas }\end{array}$ & $\begin{array}{c}\text { Desenham } \\
\text { a parte } \\
\text { que mais } \\
\text { gostaram }\end{array}$ & $\begin{array}{c}\text { Estudo } \\
\text { do Meio }\end{array}$ & $\begin{array}{c}\text { Formação } \\
\text { Cívica }\end{array}$ \\
\hline \multirow{3}{*}{ Masculino } & Média & ,9583 & ,7083 & ,6667 & ,2083 & ,7500 &, 5833 & ,4583 \\
\hline & $\mathbf{N}$ & 24 & 24 & 24 & 24 & 24 & 24 & 24 \\
\hline & $\begin{array}{l}\text { Desvio } \\
\text { Padrão }\end{array}$ & ,20412 & ,46431 & ,48154 & ,41485 & ,44233 & ,50361 & ,50898 \\
\hline \multirow{3}{*}{ Feminino } & Média & 1,0000 & ,7182 & 6818 & ,3364 & ,8727 & ,7000 & ,7273 \\
\hline & $\mathbf{N}$ & 110 & 110 & 110 & 110 & 110 & 110 & 110 \\
\hline & $\begin{array}{l}\text { Desvio } \\
\text { Padrão }\end{array}$ & ,00000 & ,45194 & ,46790 &, 47463 &, 33480 & ,46035 & ,44740 \\
\hline \multirow{3}{*}{ Total } & Média & ,9925 & ,7164 & ,6791 & ,3134 & ,8507 & ,6791 & ,6791 \\
\hline & $\mathbf{N}$ & 134 & 134 & 134 & 134 & 134 & 134 & 134 \\
\hline & $\begin{array}{l}\text { Desvio } \\
\text { Padrão }\end{array}$ & ,08639 & ,45243 & ,46857 & ,46563 & ,35768 & ,46857 & 46857, \\
\hline
\end{tabular}

Tabela 7: Escolha de livros para a sala de aula por grupo

Na generalidade, é observável uma menor adesão a esse tipo de procedimentos, no contexto letivo, bastando para tal observar as médias grupais para os seis aspetos em análise. As médias do grupo feminino são sempre superiores, embora nos dois primeiros esta diferença seja mais reduzida do que nos restantes.

Em termos etários, temos de enfatizar, desde logo, a tendência de maiores valores nas médias do grupo [50 a 60] anos, nos dois primeiros aspetos, com respetivamente

ISL, vol. 4, 2015, págs. 25-50 ISNN: 2340-8685
Sardinha, M. G., Azevedo, F. J. y Rato, R (2015): Promoção da leitura na escola portuguesa: metodologias e crenças dos professores do Ensino Básico, Investigaciones Sobre Lectura, 4, 25-50. 
0.76 e 0.7 . Por outro lado, verifica-se ao nível das médias, dos últimos três aspetos, que a mais alta se encontra entre o grupo etário dos [30 a 40] anos, com respetivamente 0.93, 0.8 e finalmente 0.73. Em termos etários, existe, desta forma, como que um eixo dicotómico entre os dois primeiros aspetos para a categorias dos [50 a 60] anos e os últimos três, claramente para uma categoria etária mais nova, de [30 a 40] anos.

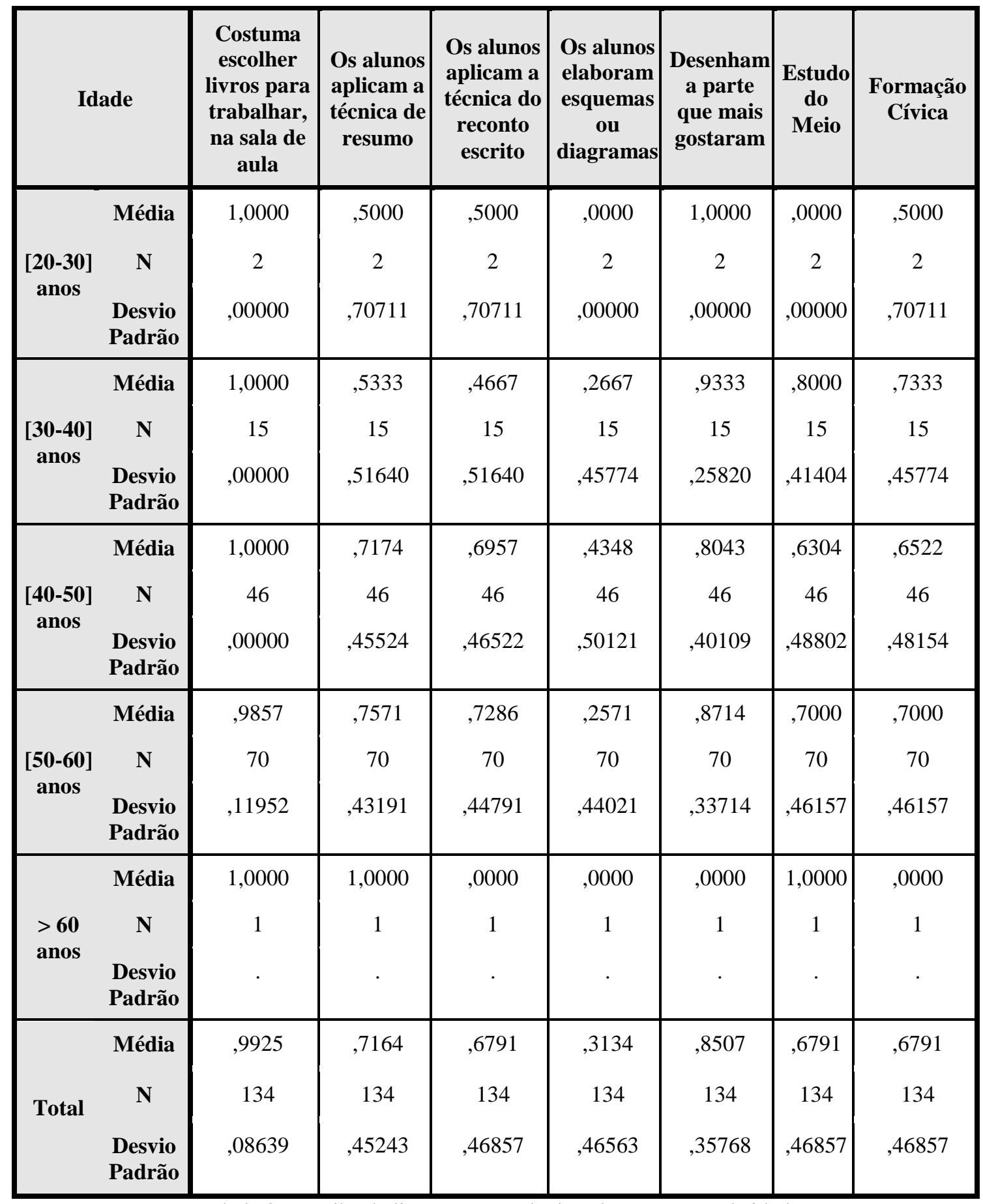

Tabela 8: Escolha de livros para a sala de aula por grupos de idade

Sardinha, M. G., Azevedo, F. J. y Rato, R (2015): Promoção da leitura na escola portuguesa: metodologias e crenças dos professores do Ensino Básico, Investigaciones Sobre Lectura, 4, 25-50. 
Passando, desde já, à análise do impacto da variável habilitações académicas, no que se refere à seleção e realização de determinadas tarefas em contexto de sala de aula, podemos adiantar que também aqui existe uma certa dicotomização, nomeadamente entre Bacharelato + Complementos e os portadores de mestrado. Refira-se que nos dois primeiros itens, o grupo que tem Bacharelato + Complementos é aquele que detém melhor média, na declaração de realização desta tipologia de tarefas, com 0.74 tanto para "os alunos aplicam a técnica de resumo", como para "Os alunos aplicam a técnica do reconto escrito". Já no que se refere aos últimos três itens, as médias mais elevadas estão localizadas entre o grupo que possui mestrado, com 1, que é a totalidade destes, mas também 0.73 e 0.64 . Embora no caso deste último exista um grupo, no caso Licenciatura em $2^{\circ}$ Ciclo do Ensino Básico - variante Português/Francês. Porém, este é apenas composto por oito elementos, o que, no plano estatístico, nos levanta algumas reservas na consideração deste valor (0.75).

\begin{tabular}{|c|c|c|c|c|c|c|c|c|}
\hline \multicolumn{2}{|c|}{$\begin{array}{l}\text { Habilitações } \\
\text { Académicas }\end{array}$} & \begin{tabular}{|c|} 
Costuma \\
escolher \\
livros \\
para \\
trabalhar, \\
na sala de \\
aula \\
\end{tabular} & \begin{tabular}{|c|} 
Os \\
alunos \\
aplicam \\
a técnica \\
de \\
resumo
\end{tabular} & $\begin{array}{c}\text { Os alunos } \\
\text { aplicam a } \\
\text { técnica do } \\
\text { reconto } \\
\text { escrito }\end{array}$ & $\begin{array}{c}\text { Os alunos } \\
\text { elaboram } \\
\text { esquemas } \\
\text { ou } \\
\text { diagramas }\end{array}$ & $\begin{array}{c}\text { Desenham } \\
\text { a parte } \\
\text { que mais } \\
\text { gostaram }\end{array}$ & $\begin{array}{c}\text { Estudo } \\
\text { do } \\
\text { Meio }\end{array}$ & $\begin{array}{c}\text { Formaç } \\
\text { ão } \\
\text { Cívica }\end{array}$ \\
\hline \multirow{3}{*}{ Bacharelato } & Média & ,9722 & 6944 & 6944 & , 2500 & ,8889 & ,7222 & ,8056 \\
\hline & $\mathbf{N}$ & 36 & 36 & 36 & 36 & 36 & 36 & 36 \\
\hline & $\begin{array}{l}\text { Desvio } \\
\text { Padrão }\end{array}$ &, 16667 & ,46718 & ,46718 & ,43916 & ,31873 & ,45426 & ,40139 \\
\hline \multirow{3}{*}{$\begin{array}{c}\text { Bacharelato } \\
+ \\
\begin{array}{c}\text { Complemento } \\
\text { s }\end{array}\end{array}$} & Média & 1,0000 & ,7368 & ,7368 & ,3509 & ,8421 & ,6842 & ,6316 \\
\hline & $\mathbf{N}$ & 57 & 57 & 57 & 57 & 57 & 57 & 57 \\
\hline & $\begin{array}{l}\text { Desvio } \\
\text { Padrão }\end{array}$ & ,00000 & ,44426 & ,44426 & 48149 & ,36788 & ,46896 & ,48666 \\
\hline \multirow{3}{*}{$\begin{array}{l}\text { Licenciatura } \\
\text { em } 1^{\circ} \text { Ciclo do } \\
\text { Ensino Básico }\end{array}$} & Média & 1,0000 & ,7222 & ,6667 & ,2222 & ,6667 & ,6111 & ,6111 \\
\hline & $\mathbf{N}$ & 18 & 18 & 18 & 18 & 18 & 18 & 18 \\
\hline & $\begin{array}{l}\text { Desvio } \\
\text { Padrão }\end{array}$ & ,00000 & ,46089 & ,48507 & ,42779 & ,48507 & ,50163 & ,50163 \\
\hline \multirow{3}{*}{$\begin{array}{c}\text { Licenciatura } \\
\text { em } 2^{\circ} \text { Ciclo do } \\
\text { Ensino Básico } \\
\text { - variante } \\
\text { Português/Fra } \\
\text { ncês }\end{array}$} & Média & 1,0000 & ,6250 & ,6250 & ,3750 & ,8750 & ,5000 & ,7500 \\
\hline & $\mathbf{N}$ & 8 & 8 & 8 & 8 & 8 & 8 & 8 \\
\hline & $\begin{array}{l}\text { Desvio } \\
\text { Padrão }\end{array}$ & ,00000 & ,51755 & ,51755 & ,51755 & ,35355 & ,53452 & 46291 \\
\hline
\end{tabular}

ISL, vol. 4, 2015, págs. $25-50$ ISNN: 2340-8685
Sardinha, M. G., Azevedo, F. J. y Rato, R (2015): Promoção da leitura na escola portuguesa: metodologias e crenças dos professores do Ensino Básico, Investigaciones Sobre Lectura, 4, 25-50. 


\begin{tabular}{|c|c|c|c|c|c|c|c|c|}
\hline $\begin{array}{c}\text { Licenciatura } \\
\text { em } 2^{\circ} \text { Ciclo do } \\
\text { Ensino Básico } \\
\text { - variante } \\
\text { Educação } \\
\text { Física }\end{array}$ & $\begin{array}{c}\text { Média } \\
\mathbf{N} \\
\text { Desvio } \\
\text { Padrão }\end{array}$ & $\begin{array}{c}1,0000 \\
1\end{array}$ & $\begin{array}{c}1,0000 \\
1\end{array}$ & $\begin{array}{c}1,0000 \\
1\end{array}$ & $\begin{array}{c}, 0000 \\
1\end{array}$ & $\begin{array}{c}1,0000 \\
1\end{array}$ & $\begin{array}{c}1,0000 \\
1\end{array}$ & $\begin{array}{c}, 0000 \\
1 \\
.\end{array}$ \\
\hline $\begin{array}{c}\text { Licenciatura } \\
\text { em } 2^{\circ} \text { Ciclo do } \\
\text { Ensino Básico } \\
\text { - variante } \\
\text { Ciências e } \\
\text { Matemática }\end{array}$ & $\begin{array}{c}\text { Média } \\
\text { N } \\
\text { Desvio } \\
\text { Padrão }\end{array}$ & $\begin{array}{c}1,0000 \\
3 \\
, 00000\end{array}$ & $\begin{array}{c}, 6667 \\
3 \\
, 57735\end{array}$ & $\begin{array}{c}, 3333 \\
3 \\
, 57735\end{array}$ & $\begin{array}{c}, 3333 \\
3 \\
, 57735\end{array}$ & $\begin{array}{c}1,0000 \\
3 \\
, 00000\end{array}$ & $\begin{array}{c}, 6667 \\
3 \\
, 57735\end{array}$ & $\begin{array}{c}, 6667 \\
3 \\
, 57735\end{array}$ \\
\hline Mestrado & $\begin{array}{c}\text { Média } \\
\mathbf{N} \\
\text { Desvio } \\
\text { Padrão }\end{array}$ & $\begin{array}{c}1,0000 \\
11 \\
, 00000\end{array}$ & $\begin{array}{c}, 7273 \\
11 \\
, 46710\end{array}$ & $\begin{array}{c}, 4545 \\
11 \\
, 52223\end{array}$ & $\begin{array}{c}, 4545 \\
11 \\
, 52223\end{array}$ & $\begin{array}{c}1,0000 \\
11 \\
, 00000\end{array}$ & $\begin{array}{c}, 7273 \\
11 \\
, 46710\end{array}$ & $\begin{array}{c}, 6364 \\
11 \\
, 50452\end{array}$ \\
\hline Total & $\begin{array}{c}\text { Média } \\
\text { N } \\
\text { Desvio } \\
\text { Padrão }\end{array}$ & $\begin{array}{c}, 9925 \\
134 \\
, 08639\end{array}$ & $\begin{array}{c}, 7164 \\
134 \\
, 45243\end{array}$ & $\begin{array}{c}, 6791 \\
134 \\
, 46857\end{array}$ & $\begin{array}{c}, 3134 \\
134 \\
, 46563\end{array}$ & $\begin{array}{c}, 8507 \\
134 \\
, 35768\end{array}$ & $\begin{array}{c}, 6791 \\
134 \\
, 46857\end{array}$ & $\begin{array}{c}, 6791 \\
134 \\
, 46857\end{array}$ \\
\hline
\end{tabular}

Tabela 9: Escolha de livros para a sala de aula por grupos de Habilitações Académicas

Ora, neste sentido, podemos recapitular a análise aqui realizada, afirmando que existe maior abertura a este tipo de atividades entre o grupo feminino de docentes inquiridos, relativamente ao grupo masculino. Em termos de idade, existem dois grupos que sobressaem na análise empírica dos dados: por um lado, um grupo mais idoso prefere um conjunto de atividades, por outro, um conjunto de mais jovens docentes que demonstra preferência por outro conjunto de tarefas. No que se refere aos anos de serviço, também ter-se-á de salientar a existência de uma certa dicotomização etária quanto às preferências declaradas. Finalmente, tomando como base analítica o grau académico, existe um grupo de docentes de mestrado que manifesta preferir um conjunto de atividades, em antagonismo com o grupo de bacharelato+ complemento que afirma preferir um outro.

O quarto e último grupo, tendo como linha condutora a análise do processo de aprendizagem da leitura e das suas múltiplas estratégias, tem, como maior desígnio, procurar entender e interpretar o modo e as estratégias adotadas pelos inquiridos, enquanto professores do $1^{\circ}$ Ciclo do Ensino Básico. Sabendo que a fase inicial da trajetória de ensino é decisiva na construção da identidade e inclusive na própria criatividade das crianças, procurou-se aferir em que estado se encontra a implementação de estratégias que dinamizem e estimulem a criatividade e o gosto pela leitura. Nesta 
medida, foram questionados os professores que dão corpo à amostra, acerca do uso regular de obras de literatura de cariz infanto-juvenil, em contexto de sala de aula.

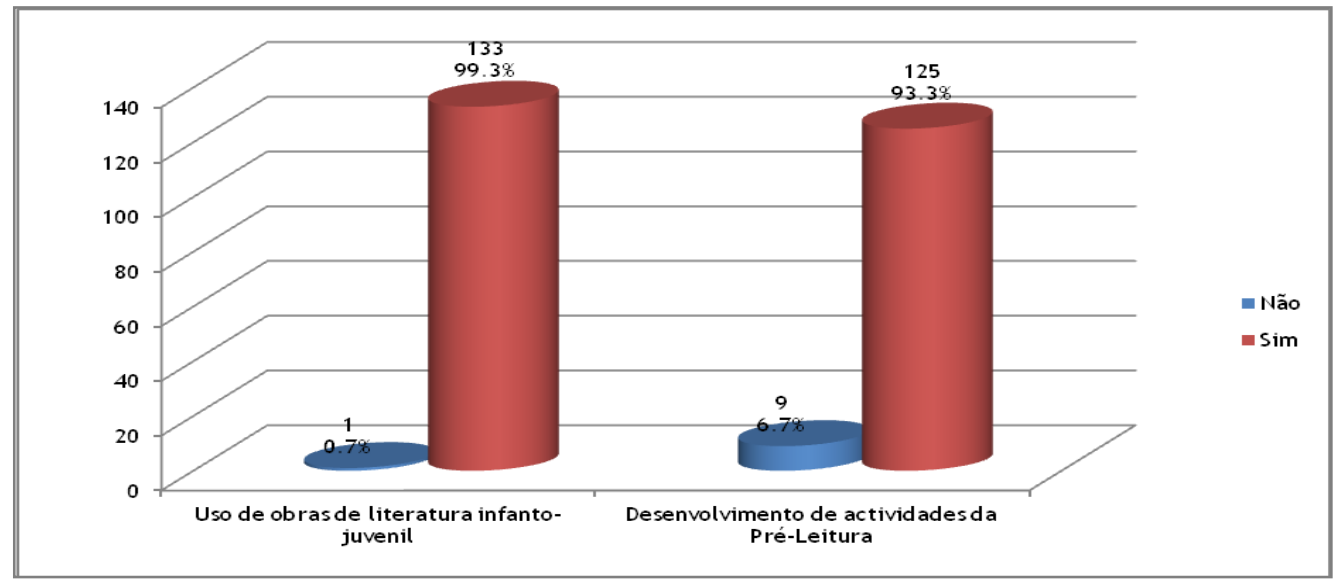

Gráfico 10: Uso e atividades com obras Infanto-juvenis

Atendendo aos resultados obtidos, sintetizados no gráfico 10, podemos afirmar que existe uma quase unanimidade entre os inquiridos acerca da recorrência, na utilização deste tipo de instrumentos, na sala de aula.

De seguida, foi solicitado aos inquiridos, ainda acerca da utilização e estudo de obras infanto-juvenis, se existe um enquadramento prévio desse estudo com a realização da Pré-Leitura. Também neste aspeto, bem na linha do que já tínhamos anteriormente verificado, existe uma expressiva maioria, que sublinha a existência e realização da PréLeitura antecedendo o estudo da obra em causa. Este fato empiricamente verificável ganha forma nos $93.3 \%$ dos inquiridos a referirem que o fazem. Em face da distribuição dos dados, perguntamo-nos quem são estes nove inquiridos? Que perfil têm eles?

Ao nível da pertença de género, cinco são homens e quatro mulheres, tendo na sua maioria idade igual ou superior a 40 anos, acumulando, com efeito, 20 ou mais anos de carreira profissional, tendo ao nível das habilitações académicas o bacharelato ou Bacharelato + Complementos.

Como podemos observar na tabela 10, o grupo feminino apresenta, invariavelmente, médias superiores ao grupo masculino, embora em alguns casos esta seja mínima. Ainda assim, podemos identificar na "motivação para o estudo da obra" como sendo aquela, como a preferida pelos homens com 0.71 , que, aliás, apresenta uma média bem similar à do grupo feminino (0.71). Aliás, esta opção, em jeito de significado, é também a preferida por parte das docentes inquiridas. Por outro lado, nos antípodas da situação descrita, encontra-se a "ativação do conhecimento temático" que desempenha o papel de menor preferência entre ambos os grupos em estudo.

ISL, vol. 4, 2015, págs. 25-50 ISNN: $2340-8685$
Sardinha, M. G., Azevedo, F. J. y Rato, R (2015): Promoção da leitura na escola portuguesa: metodologias e crenças dos professores do Ensino Básico, Investigaciones Sobre Lectura, 4, 25-50. 


\begin{tabular}{|c|c|c|c|c|c|}
\hline \multicolumn{2}{|l|}{ Género } & $\begin{array}{c}\text { Ativação do } \\
\text { conhecimento } \\
\text { temático }\end{array}$ & $\begin{array}{c}\text { Motivação para } \\
\text { o estudo da } \\
\text { obra }\end{array}$ & $\begin{array}{l}\text { Adivinhação } \\
\text { sobre o } \\
\text { conteúdo da } \\
\text { obra }\end{array}$ & Outro (s) \\
\hline \multirow{3}{*}{ Masculino } & Média & ,4583 & ,7083 &, 5000 & 0833 \\
\hline & $\mathbf{N}$ & 24 & 24 & 24 & 24 \\
\hline & Desvio Padrão & ,50898 & ,46431 &, 51075 & ,28233 \\
\hline \multirow{3}{*}{ Feminino } & Média & ,5000 & ,7091 &, 5455 &, 0545 \\
\hline & $\mathbf{N}$ & 110 & 110 & 110 & 110 \\
\hline & Desvio Padrão &, 50229 & ,45626 &, 50021 & ,22813 \\
\hline \multirow{3}{*}{ Total } & Média & ,4925 & ,7090 &, 5373 & 0597 \\
\hline & $\mathbf{N}$ & 134 & 134 & 134 & 134 \\
\hline & Desvio Padrão &, 50182 & 45595 & ,50048 & ,23782 \\
\hline
\end{tabular}

Tabela 10: Significados da Pré-leitura, por Género

Com a terceira bateria de questões, definiu-se como desígnio a análise das atividades, potencialmente desenvolvidas ao longo do processo de leitura. Numa primeira abordagem, aos dados contidos no gráfico 11, podemos, desde logo, reter de que se trata de uma maioria, aquela que declara realizar atividades ao longo da leitura. Concluímos isso, em face dos dados obtidos com a primeira das questões, que confrontava os inquiridos com a possibilidade "nenhuma" atividade desenvolvida neste âmbito. São apenas cerca de $7.5 \%$ aqueles que referem nunca o fazer. Igualmente a opção "outras" apresenta uma distribuição de dados relativamente similar, visto que são apenas $14.9 \%$ dos inquiridos que realiza outro tipo de atividades não mencionadas no presente inquérito. Efetivamente, das tarefas realizadas, apenas uma obtém uma maioria, que confirma a realização desta tarefa, no contexto indicado. A "apresentação de pequenos excertos da obra", apresenta uma distribuição de dados onde o sim pontifica com $65.7 \%$. Já a atividade que consiste no "preenchimento de grelhas/tabelas" é pautada por um forte equilíbrio, na respetiva distribuição dos dados. Com o "não" a atingir a marca dos $54.5 \%$.

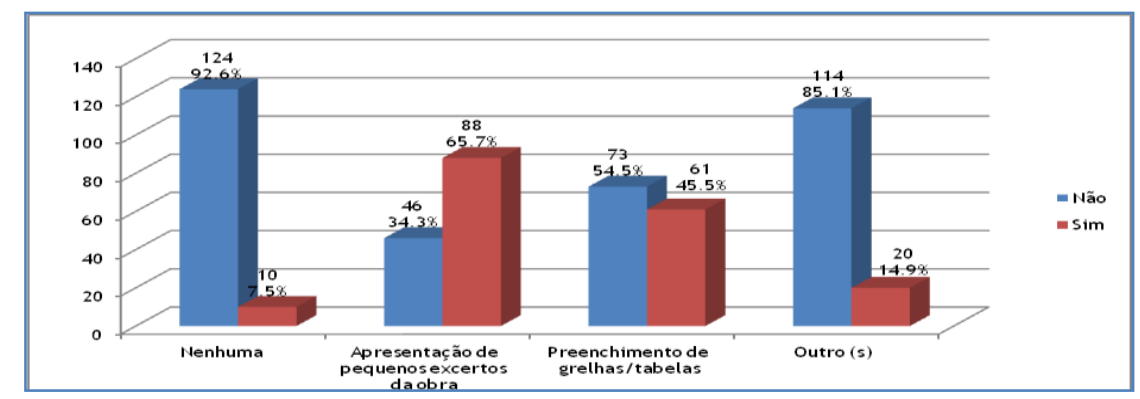

Gráfico 11: Atividades desenvolvidas ao longo da leitura 
Na tabela 11, são apresentadas as médias dos diversos grupos etários, para as diferentes atividades. Neste sentido, as atividades em apreço indiciam, através das respetivas médias, que estas estão mais impregnadas nas práticas dos grupos etários mais novos. Tomando como exemplo a "apresentação de pequenos excertos da obra" 0.73 para [30 a 40] anos, sendo que para o grupo dos [50 a 60] anos a média é apenas de 0.64. Na mesma linha, acontece o "preenchimento de grelhas/tabelas," que no grupo [30 a 40] anos é de 0.53 , já para o grupo [50 a 60] anos, a média não vai além dos 0.4 , tal como se pode observar na tabela 11. Na mesma sequência, surge o papel desempenhado pela variável anos de serviço. A exceção é precisamente "apresentação de pequenos excertos da obra", em que assistimos a uma inversão desta tendência, ainda que com pouca intensidade.

\begin{tabular}{|c|c|c|c|c|c|}
\hline \multicolumn{2}{|c|}{ Idade } & Nenhuma & $\begin{array}{c}\text { Apresentação } \\
\text { de pequenos } \\
\text { excertos da } \\
\text { obra }\end{array}$ & $\begin{array}{c}\text { Preenchimento } \\
\text { de } \\
\text { grelhas/tabelas }\end{array}$ & Outro (s) \\
\hline \multirow{3}{*}[20-30]{ anos } & Média & ,0000 & ,5000 & 1,0000 &, 0000 \\
\hline & $\mathbf{N}$ & 2 & 2 & 2 & 2 \\
\hline & Desvio Padrão & ,00000 &, 70711 & ,00000 & ,00000 \\
\hline \multirow{3}{*}[30-40]{ anos } & Média & , 0000 &, 7333 & ,5333 & ,2000 \\
\hline & $\mathbf{N}$ & 15 & 15 & 15 & 15 \\
\hline & Desvio Padrão &, 00000 & ,45774 & ,51640 & ,41404 \\
\hline \multirow{3}{*}[40-50]{ anos } & Média & ,0435 & ,6522 & ,5000 &, 1739 \\
\hline & $\mathbf{N}$ & 46 & 46 & 46 & 46 \\
\hline & Desvio Padrão & ,20618 &, 48154 &, 50553 & ,38322 \\
\hline \multirow{3}{*}[50-60]{ anos } & Média & , 1143 & ,6429 & ,4000 &, 1286 \\
\hline & $\mathbf{N}$ & 70 & 70 & 70 & 70 \\
\hline & Desvio Padrão & ,32046 & ,48262 & ,49344 & ,33714 \\
\hline \multirow{3}{*}{$>60$ anos } & Média & ,0000 & 1,0000 & 0000 &, 0000 \\
\hline & $\mathbf{N}$ & 1 & 1 & 1 & 1 \\
\hline & Desvio Padrão & . & 5 & . & . \\
\hline \multirow{3}{*}{ Total } & Média & ,0746 & ,6567 & , 4552 & ,1493 \\
\hline & $\mathbf{N}$ & 134 & 134 & 134 & 134 \\
\hline & Desvio Padrão & ,26377 & ,47659 & ,49986 & ,35768 \\
\hline
\end{tabular}

Tabela 11: Desenvolvimento de atividades durante a leitura por idade

No sentido de traçar as linhas gerais da presente análise, diríamos que se observa ampla aplicação de atividades durante a fase de leitura, sendo que estas estão mais vincadamente impregnadas nas práticas docentes entre os elementos inquiridos do género masculino. No que diz respeito à idade, verificámos que esta assume especial relevância entre os escalões etários mais jovens dos docentes. O papel da variável anos de serviço apresenta-se-nos como dual, nas duas tarefas em causa, apresentando

ISL, vol. 4, 2015, págs. $25-50$ ISNN: 2340-8685
Sardinha, M. G., Azevedo, F. J. y Rato, R (2015): Promoção da leitura na escola portuguesa: metodologias e crenças dos professores do Ensino Básico, Investigaciones Sobre Lectura, 4, 25-50. 
tendências distintas. No que respeita à variável habilitações académicas, teremos de referir que existem indícios de uma dictomização, no que se refere à preferência por determinada atividade, onde os bacharéis preferem "Apresentação de pequenos excertos da obra" enquanto, que os mestres preferem o "Preenchimento de grelhas/tabelas".

$\mathrm{Na}$ última bateria de questões, era solicitado aos inquiridos que indicassem se realizam exercícios Pós-Leitura e, em caso afirmativo o que efetivamente executam em contexto de aula. Numa primeira e genérica abordagem (gráfico 12), dir-se-á que existe uma fortíssima proeminência entre os docentes inquiridos, isto face aos resultados obtidos pela distribuição empírica, no que concerne à questão que confrontava os inquiridos a respeito da realização, ou não, desta tipologia de atividades. Concretizando, diríamos que temos quase unanimidade entre os inquiridos, relativamente ao aspeto em análise, dado que apenas obtivemos um inquirido que respondeu negativamente, o que em termos relativos se traduz em $99.3 \%$ que responderam afirmativamente.

No que respeita às tarefas propriamente ditas, todas elas reúnem um relativo consenso, porque o item que consiste na construção de "resumo do texto", apresenta algum equilíbrio, isto é com $46.3 \%$ a responder não realizar, e os restantes $53.7 \%$ a declarar fazê-lo. Nas restantes três atividades, verificamos que todas elas ascendem invariavelmente aos $65 \%$.

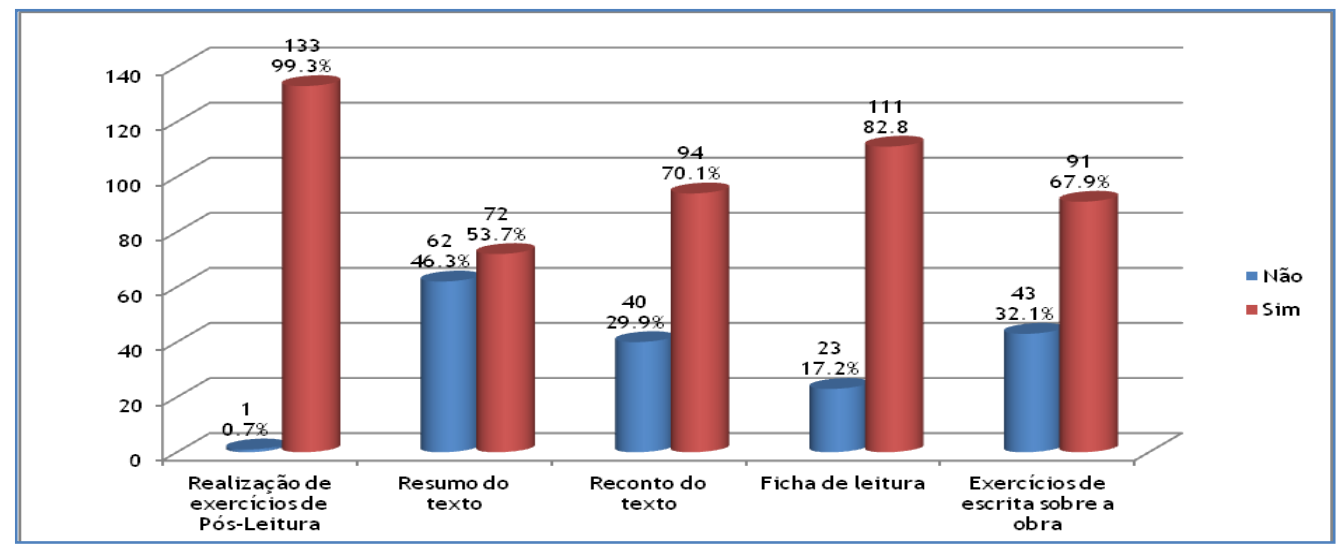

Gráfico 12: Exercícios Pós-Leitura

\section{Em jeito de conclusão}

Os dados revelados por este inquérito mostram-nos uma situação que merece a nossa atenção. Os professores inquiridos, predominantemente do sexo feminino, têm uma longa carreira de trabalho, sendo detentores de formação a nível de bacharelato e com complementos de formação. Um grande número deles não parece ter hábitos de leitura de livros enraizados nem tão pouco frequentar, com assiduidade, e na companhia dos alunos, as bibliotecas escolares / centros de recursos educativos (BE/CRE). Embora as parcerias com as BE/CRE sejam reduzidas são os professores licenciados que promovem os hábitos de leitura, ao motivarem os alunos para a requisição de livros. 
Os resultados estatísticos demonstram igualmente que os professores com o grau de mestre têm por hábito escolher livros para trabalhar com os alunos em sala de aula, estimulando mais os alunos a realizar uma série de atividades (técnica do resumo, do reconto, elaboração de organizadores gráficos) do que os professores com a formação de bacharelato e complementos de formação. A relevância da formação especializada de professores, com o aprofundamento das matérias curriculares e a inclusão de unidades curriculares do âmbito da didática da leitura e da literatura permite resultados mais satisfatórios quando se trata de promover a leitura junto dos alunos.

Estes dados revelaram também que o professor, enquanto mediador da leitura, deverá assumir um papel interventivo capaz de conferir um estímulo aprazível ao ato de ler. Assim, torna-se necessário apostar na formação contínua dos professores, fazendo deles verdadeiros professores leitores, porque, como diz Pedro Cerrillo (2006), não haverá comportamentos leitores se os professores não souberem ser verdadeiros mediadores de leitura.

\section{Referências}

Cerrillo, P. (2006). Literatura Infantil e mediação leitora. En F. Azevedo (Coord.), Língua materna e literatura infantil para professores do ensino básico (pp. 3346). Lisboa: Lidel.

Dewitz, P., Leahy, S.B., Jones, J. \& Maslin Sullivan, P. M. (2010). Developing comprehension with core reading programs. En P. Dewitz, S. B. Leahy, J. Jones, \& P. M. Maslin Sullivan (eds.), The essential guide to selecting and using core reading programs (pp. 281-308). Newark, DE: International Reading Association.

Kelley, M. J. \& Clausen-Grace, N. (Eds.) (2013), Comprehension shouldn't be silent. from strategy instruction to student independence. Newark, D. E.: International Reading Association.

ISL, vol. 4, 2015, págs. 25-50 ISNN: $2340-8685$
Sardinha, M. G., Azevedo, F. J. y Rato, R (2015): Promoção da leitura na escola portuguesa: metodologias e crenças dos professores do Ensino Básico, Investigaciones Sobre Lectura, 4, 25-50. 